\title{
Contemporary Mouse Models in Glioma Research
}

\author{
William H. Hicks ${ }^{1,+}{ }^{\mathbb{D}}$, Cylaina E. Bird ${ }^{1,+}{ }^{+}$, Jeffrey I. Traylor ${ }^{1} \mathbb{D}$, Diana D. Shi ${ }^{2}$, Tarek Y. El Ahmadieh ${ }^{1}$, \\ Timothy E. Richardson ${ }^{3}$ (D), Samuel K. McBrayer ${ }^{4,5, *}$ and Kalil G. Abdullah 1,5,6,*
}

1 Department of Neurological Surgery, University of Texas Southwestern Medical Center, Dallas, TX 75235, USA; william.hicks@UTSouthwestern.edu (W.H.H.); cylaina.bird@utsouthwestern.edu (C.E.B.); jeffrey.traylor@utsouthwestern.edu (J.I.T.); tarek.elahmadieh@phhs.org (T.Y.E.A.)

2 Department of Radiation Oncology, Brigham and Women's Hospital and Dana-Farber Cancer Institute, Harvard Medical School, Boston, MA 02215, USA; dshi1@partners.org

3 Department of Pathology, Glenn Biggs Institute for Alzheimer's and Neurodegenerative Diseases, University of Texas Health San Antonio, San Antonio, TX 75229, USA; richardson.te@gmail.com

4 Children's Medical Center Research Institute, University of Texas Southwestern Medical Center, Dallas, TX 75390, USA

5 Harrold C. Simmons Comprehensive Cancer Center, University of Texas Southwestern Medical Center, Dallas, TX 75235, USA

6 Peter O'Donnell Jr. Brain Institute, University of Texas Southwestern Medical Center, Dallas, TX 75235, USA

* Correspondence: samuel.mcbrayer@utsouthwestern.edu (S.K.M.); kalil.abdullah@utsouthwestern.edu (K.G.A.)

+ These authors contributed equally to this work.

Citation: Hicks, W.H.; Bird, C.E.;

Traylor, J.I.; Shi, D.D.; El Ahmadieh, T.Y.; Richardson, T.E.; McBrayer, S.K.; Abdullah, K.G. Contemporary Mouse Models in Glioma Research. Cells 2021, 10, 712. https://doi.org/ $10.3390 /$ cells10030712

Academic Editor: Chun Zhang Yang

Received: 3 March 2021

Accepted: 20 March 2021

Published: 23 March 2021

Publisher's Note: MDPI stays neutral with regard to jurisdictional claims in published maps and institutional affiliations.

\section{Copyright: (c) 2021 by the authors.} Licensee MDPI, Basel, Switzerland. This article is an open access article distributed under the terms and conditions of the Creative Commons Attribution (CC BY) license (https:/ / creativecommons.org/licenses/by/ $4.0 /)$.

\begin{abstract}
Despite advances in understanding of the molecular pathogenesis of glioma, outcomes remain dismal. Developing successful treatments for glioma requires faithful in vivo disease modeling and rigorous preclinical testing. Murine models, including xenograft, syngeneic, and genetically engineered models, are used to study glioma-genesis, identify methods of tumor progression, and test novel treatment strategies. Since the discovery of highly recurrent isocitrate dehydrogenase (IDH) mutations in lower-grade gliomas, there is increasing emphasis on effective modeling of IDH mutant brain tumors. Improvements in preclinical models that capture the phenotypic and molecular heterogeneity of gliomas are critical for the development of effective new therapies. Herein, we explore the current status, advancements, and challenges with contemporary murine glioma models.
\end{abstract}

Keywords: glioma; genetically engineered mouse models (GEMM); isocitrate dehydrogenase (IDH); patient-derived xenograft (PDX); mouse model

\section{Introduction}

Diffuse gliomas are the most common primary tumor of the central nervous system (CNS) and are currently classified as lower-grade glioma (WHO grade II and III) or glioblastoma (GBM; WHO grade IV) based on a combination of histologic and molecular features [1]. Based on the histologic similarity of the tumor to glial cells, diffuse glioma is a broad term encompassing astrocytoma, oligodendroglioma, each of their anaplastic variants, and GBM [1]. Lower-grade gliomas tend to be slower growing and are less aggressive than higher grade gliomas, with the diagnosis of GBM conferring a dismal prognosis [1] Despite advances in treatment, patients with GBMs have a median survival of 15 months and a 5 -year survival rate of $<10 \%$ with maximal resection and concomitant chemotherapy and radiation [1]. The intractability of these tumors highlights the need for clinical testing of new therapies that display robust activity in accurate mouse models of glioma.

In vivo cancer modeling provides numerous advantages over in vitro modeling. Over $80 \%$ of the genes in the mouse genome have direct human orthologs, thereby leading to adoption of the mouse as the dominant model organism for cancer biology and cancer therapy studies [2]. Recent advances in genetic engineering have enabled the production 
of mouse models of glioma that increasingly mimic the microenvironmental and genomic characteristics of human brain tumors. The genetic landscape of glioma is characterized by alterations in genes encoding epidermal growth factor receptor (EGFR), phosphate and tensin homolog deleted on chromosome 10 (PTEN), neurofibromatosis 1 (NF1), RAS, TP53, and cyclin dependent kinase inhibitor 2 (CDKN2A/B), among others, leading to cell proliferation and tumorigenesis [3,4]. Recently, mutations in isocitrate dehydrogenase 1 and 2 (IDH1/2) have been identified in the majority of lower-grade gliomas and a relatively small subset of GBMs [3,5]. As lower-grade gliomas invariably progress to secondary GBMs, evaluating the role of IDH directed therapy is important for patient care.

Recapitulation of the diffuse and infiltrative nature of glioma has been challenging to achieve in murine glioma models. Gliomas do not display the well-circumscribed morphology typical of many other solid tumors. Therefore, representing this unique property of these cancers in mice is desirable in order to accurately model tumor-stroma interactions and glioma cell behavior. Over the last 10 years, substantial advances in the understanding of the molecular pathogenesis of glioma have prompted updates to the WHO classifications system for glioma (combining both histopathological and molecular tumor characteristics) and have guided efforts to develop new targeted therapies and murine models for this disease [5]. The genetic diversity, inter- and intra-tumoral heterogeneity, and extensive interaction with brain parenchyma displayed by gliomas lead to late clinical detection, resistance to treatment, and universal tumor recurrence following therapy. These features highlight the need for efficient and representative preclinical mouse models of glioma [6,7]. In this review, the evolution, history, and current status of contemporary glioma mouse models is discussed.

\section{Evolution of Cancer Mouse Models}

Cancer mouse models evolved alongside advances in molecular and medical technology and vary in cost and immune status (Table 1). A visual summary of the distinct types of mouse models discussed in this article are provided in Figure 1.

Table 1. Comparison of preclinical animal model features.

\begin{tabular}{ccccc}
\hline Model & Tumor Source & Immune Status & Cost & Labor/Time \\
\hline CLX & Human & $(-)$ & $\$$ & + \\
PDX & Human & $(-)$ & $\$ \$$ & ++ \\
Syngeneic & Mouse & $(+)$ & $\$$ & ++ \\
GEMM & Mouse & $(+)$ & $\$ \$ \$$ & +++ \\
\hline
\end{tabular}

CLX, cell-line xenograft; PDX, patient-derived xenograft; GEMM, genetically engineered mouse model.

CLX, cell-line xenograft; PDX, patient-derived xenograft; GEMM, genetically engineered mouse model.

The first cancer animal model was the xenograft model. Historically, this model achieved tumor growth through hetero-transplantation of human cancer cells into immuneprivileged sites like the guinea pig eye or hamster cheek-pouch [8]. While effective as an animal culture of the tumor, these early models provided limited opportunity for study of tumor interaction with native tissue cell types and precluded orthotopic transplantation (into the organ of origin). This challenge was overcome in 1953, when cortisone-treated, irradiated rat xenograft models grew transplanted human tumors [9]. Rygaard and Paulson (1969) further established an immune-compromised host as a critical tool for effective tumor xenograft transplantation [10]. Engraftment rates were significantly improved by immunecompromised mice which led to widespread adoption of xenograft models in the cancer research field [11].

Around the time that the first xenograft models were established, syngeneic models were created to facilitate the identification of effective chemotherapies [12]. From the 1950s to 1970s, the National Cancer Institute conducted chemotherapeutic screening programs using syngeneic models of sarcoma 180, L1210 leukemia, B16 melanoma, and P388 leukemia, 
among others [12]. Syngeneic models are created through the use of carcinogens or genetic modification to induce tumorigenesis or by leveraging spontaneous tumor formation in the mouse $[13,14]$. Malignant transformation can be induced in vitro or in vivo. If primary cells are transformed in vitro, they can be introduced to an organism of the same species. C57BL/6, BALBc, and FVB/N are common mouse species used in syngeneic models and have been critical for the preclinical evaluation of experimental therapeutics $[13,14]$. Xenograft and syngeneic modeling approaches have been applied extensively to glioma research, as summarized below.

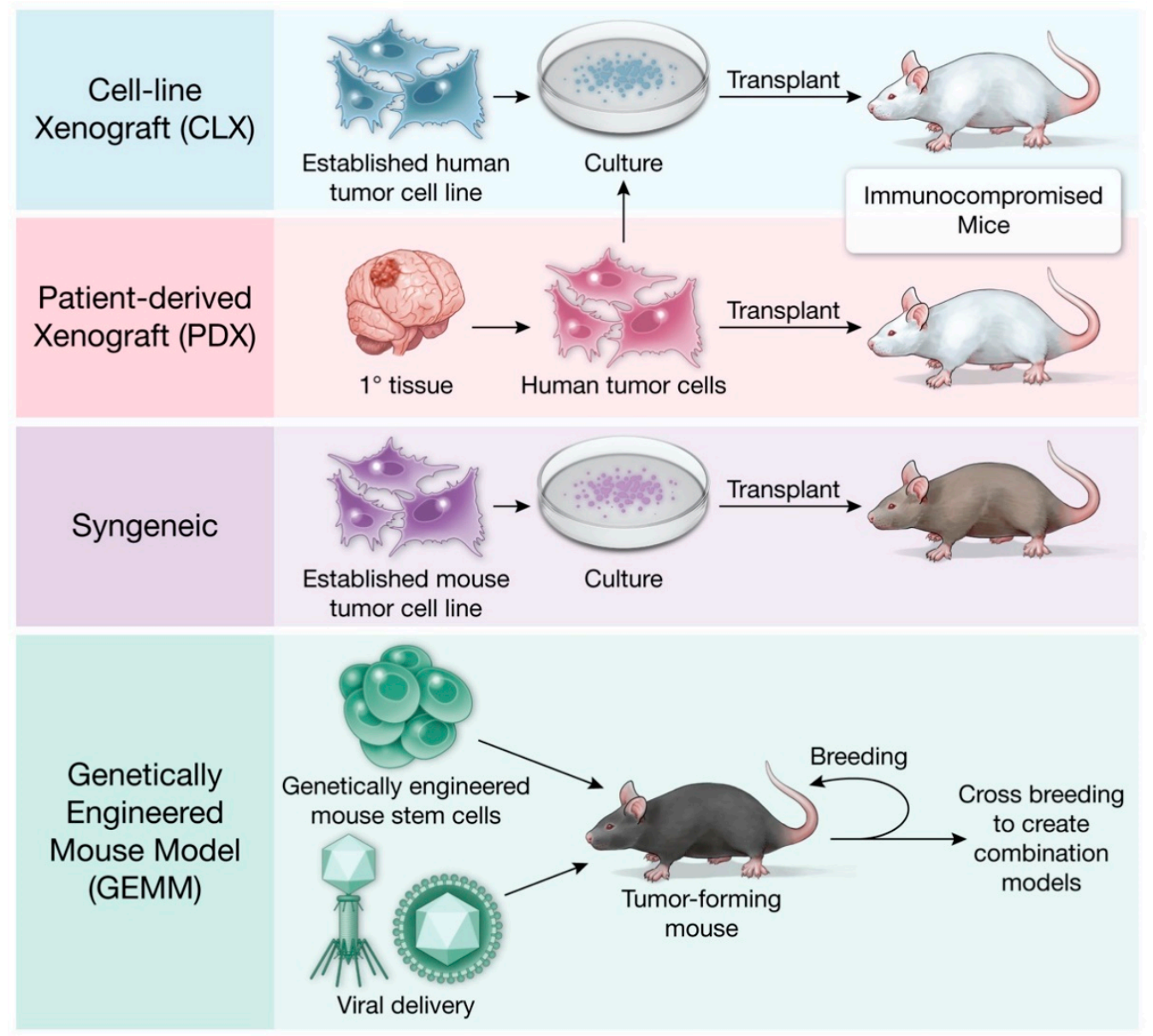

Figure 1. Murine preclinical cancer modeling.

Genetically engineered mouse models (GEMMs) were first established when oncogenic viral DNA was detected in the adult mouse following transfection of the mouse embryo with simian virus 40 (SV40) [15]. In the 1980s, there was a rapid expansion of transgenic GEMMs with the creation of onco-mice [16-18]. These onco-mice have tumorigenic DNA, often known or proposed oncogenes, introduced into their genome to create a mouse predisposed to tumor formation. Subsequent models placed the oncogene under tissue specific promoters, like the pairing of the immunoglobulin enhancer to the Myc gene to model B-cell lymphomas or the hormone inducible mouse mammary tumor virus-Ras mouse to model breast cancer [17,19]. Gu et al. (1993) established the Cre-loxP system as a conditional gene targeted tool for genetic recombination [20]. A similar model was simultaneously developed utilizing the Flp-FRT system [21]. These molecular tools led to the development of conditional inducible mouse models of cancer and are discussed at greater length later in the review. As our genetic and molecular understanding of specific cancers, including glioma, continues to grow, individual genetically engineered mice can be bred to generate combinatorial genetic defects that better resemble the multi-allelic abnormalities in human cancer. 


\section{Xenograft Models}

Historically, orthotopic high grade glioma (HGG) xenograft models were created with patient-derived cell lines or established cell lines. In cell-line xenograft models (CLX), cells are implanted into the desired location in the mouse (Table 2). For glioma CLXs, immortalized glioma cell lines commonly used for implantation include U87, U251, T98G and A172 [22,23]. CLXs are a quick and reproducible strategy for studying glioblastoma. However, they often result in well-circumscribed tumors that lack the characteristic infiltrative pattern that is observed in human gliomas [22,23]. Further, the selective pressures of cell culture reduce the sub-clonal heterogeneity of CLXs and their ability to recapitulate the parent tumor [24]. Advances in CLX modeling have been driven by the isolation and propagation of glioma stem-like cell (GSC) lines, which are commonly identified by the cell surface antigen $\mathrm{CD} 133$ and retain expression of stemness markers that are readily observed in human glioma [25]. GSC lines are propagated as neuro-sphere cultures using ultra-low adherence culture vessels and serum free media containing neural cell-specific growth factors. In contrast to CLX models, patient-derived xenografts models (PDX) involve direct xenotransplantation of human biopsy tissue (Table 3). Importantly, PDX models are exposed minimally, if at all, to in vitro culture, which avoids adaptation to non-physiological conditions and preserves features of the tumor of origin. PDX models have been shown to better recapitulate the vascular characteristics and blood brain barrier permeability of patient HGGs as compared to CLX tumors derived from the U87 cell line [22,23]. Thus, PDX models are better suited to recapitulate the stromal and interactions and invasiveness of parent tumors than their CLX counterparts. Xenograft models have been used extensively in the study of glioma biology [26-28]. In 1986, Kaye et al. were one of the first to create a model using this system by implanting a C6 glioma cell line (a rat glioma cell line) into neonatal and adult mice to demonstrate a reliable murine xenograft glioma model [27]. When creating a reliable xenograft model, the location of cancer cell implantation needs to be precise for development of a tumor that accurately recapitulates the human counterpart [28]. Iretenkauf et al. (2017) utilized a glioma xenograft model with nude mice and showed that the implantation location of GSCs within the brain can affect the developed tumor characteristics in the murine model [28].

Table 2. Glioma cell-line xenograft (CLX) and syngeneic murine models.

\begin{tabular}{|c|c|c|c|}
\hline Mouse Species & Brain Tumor Modeled & Tumor Cell Line & Reference \\
\hline BALB/c OlaHsd-Foxn $1^{\text {nu }}$ & Glioma & BT3 cells & [29] \\
\hline \multirow{2}{*}{ C57BL6/N } & High Grade Glioma & GL261 cells & [30-37] \\
\hline & High Grade Glioma & U87 and GL261 cells & [38] \\
\hline $\begin{array}{l}\text { CBA, BALB/c, AKR, C57 } \\
\text { black, and RIII }\end{array}$ & Glioma & Rat C6 cells & [27] \\
\hline $\begin{array}{l}\text { CD-1, Nude, and NOD } \\
\text { CRISPR Prkdc IL2R } \gamma_{\text {null }}\end{array}$ & Glioma & DAOY and T98G cells & [39] \\
\hline CIEA-NOG & Glioblastoma (GBM) & Patient derived glioma cell lines & [40] \\
\hline C6B3F1 & High Grade Glioma & $\begin{array}{l}\text { Mouse Tu2449, Tu9648 and Tu251 mouse } \\
\text { glioma cell lines }\end{array}$ & [41] \\
\hline Foxn $1^{\text {nu/nu }}$ & Glioma & BT4C cells & {$[29,42]$} \\
\hline ICR & High Grade Glioma & C6 rat glioma cells & {$[43]$} \\
\hline \multirow{3}{*}{$\begin{array}{c}\text { Non-obese/diabetic } \\
\text { (NOD)/Severe combined } \\
\text { immunodeficient (SCID) }\end{array}$} & $\begin{array}{l}\text { Isocitrate dehydrogenase } 1 \\
\text { (IDH1) Mutated Glioma }\end{array}$ & Patient derived IDH1 mutant oligoastrocytoma & [44] \\
\hline & GBM & TG1 human GBM cell line & [45] \\
\hline & GBM & T98 and U87 glioma cell lines & [46] \\
\hline
\end{tabular}


Table 2. Cont.

\begin{tabular}{|c|c|c|c|}
\hline Mouse Species & Brain Tumor Modeled & Tumor Cell Line & Reference \\
\hline Nude/NOD/SCID & High Grade Glioma & U87, U118, LN18, LN229 cell lines & [47] \\
\hline Not reported & GBM & U87 and U373 glioma cell lines & [48] \\
\hline \multirow{29}{*}{ Nude } & GBM & Ink4a/ARF ${ }^{-/-}$Id 4 astrocyte cells & [49] \\
\hline & Malignant Astrocytoma & Commercial malignant cell lines & [50] \\
\hline & High Grade Glioma & BT70 malignant glioma cell line & {$[51]$} \\
\hline & High Grade Glioma & $\begin{array}{l}\text { U87 human glioma cell line and C6 rat glioma } \\
\text { cell line }\end{array}$ & [52] \\
\hline & GBM & LN229 and U87 human glioma cells & [53] \\
\hline & High Grade Glioma & E98 and E473 glioma cell lines & [54] \\
\hline & GBM & Mouse GL261 cell line & [55] \\
\hline & GBM & $\begin{array}{l}\text { Human U87 glioma and rat 9L glio-sarcoma } \\
\text { cell lines }\end{array}$ & [56] \\
\hline & GBM & Patient derived GBM cell lines & {$[57-59]$} \\
\hline & High Grade Glioma & $\begin{array}{l}\text { Human astroglioma U373 and T98G and } \\
\text { oligodendroglioma Hs683 cell lines }\end{array}$ & {$[60]$} \\
\hline & High Grade Glioma & $\begin{array}{l}\text { Human glioma U87, U251, U373, A172, LN18, } \\
\text { LN229, and D54 cell lines }\end{array}$ & {$[61]$} \\
\hline & High Grade Glioma & Hs683 cells & [62] \\
\hline & High Grade Glioma & LN229 cells & {$[63,64]$} \\
\hline & High Grade Glioma & SHG44 cells & [65] \\
\hline & High Grade Glioma & T98G and U373 cells & {$[66]$} \\
\hline & High Grade Glioma & U87, U251 and D566 cells & {$[67]$} \\
\hline & High Grade Glioma & U87 cells & [68-90] \\
\hline & GBM & U87. LNZ308, LN229 cells & [91] \\
\hline & High Grade Glioma & $\begin{array}{l}\text { U87, U118, N10, U251, A172, and U373 cell } \\
\text { lines }\end{array}$ & [92] \\
\hline & High Grade Glioma & U251 cell line & {$[93,94]$} \\
\hline & GBM & U87 and LN229 cell lines & [95] \\
\hline & GBM & LN229 cell line & [96] \\
\hline & Glioma & E102 and E106 glioma cell lines & [97] \\
\hline & Glioma & $\begin{array}{l}\text { SNB-19 U87 glioma cell lines with } \\
\text { co-transfecting COS-7 cells with pTet-On and } \\
\text { treated with doxycycline }\end{array}$ & [98] \\
\hline & High Grade Glioma & $\begin{array}{l}\text { Human T269 4IgB7H3 knockdown or control } \\
\text { cells (orthotopic); LN-229 4IgB7H3 knockdown } \\
\text { or control cells (subcutaneous) }\end{array}$ & [99] \\
\hline & High Grade Glioma & U87 and U251 glioma cell lines & {$[100]$} \\
\hline & Glioma & A-172, U343, U87 and T98G glioma cells & [101] \\
\hline & Glioma & U87 glioma cell line & [102] \\
\hline & Glioma & U373 human glioma cell line & {$[103]$} \\
\hline \multirow{2}{*}{ SCID } & High Grade Glioma & GLI36-EGFRvIII engineered cells & [104] \\
\hline & Glioma & Patient-derived GSC lines & [105-107] \\
\hline
\end{tabular}


Table 3. Glioma patient-derived xenograft (PDX) murine models.

\begin{tabular}{|c|c|c|c|}
\hline Mouse Species & $\begin{array}{l}\text { Brain Tumor } \\
\text { Modeled }\end{array}$ & Source of Tumor Cells & Reference \\
\hline $\begin{array}{l}\text { eGFP NOD/SCID } \\
\text { mice }\end{array}$ & Oligodendroglioma & Patient-derived tumor cells & [108] \\
\hline $\begin{array}{l}\text { NOD-Prkdc SCID } \\
\text { IL2R } \gamma_{\text {null }}\end{array}$ & Grade II-IV Glioma & Patient-derived glioma tissue & [109] \\
\hline \multirow{2}{*}{ NOD-SCID } & $\begin{array}{l}\text { Malignant } \\
\text { Astrocytoma }\end{array}$ & Embryonic stem cells & [110] \\
\hline & Glioma & $\begin{array}{l}\text { Patient-derived high grade } \\
\text { glioma tissue }\end{array}$ & [111] \\
\hline $\begin{array}{c}\mathrm{NOD} / \mathrm{SCID} \mathrm{Il} 2 \mathrm{rg}^{-/-} \\
\text {(NOG) }\end{array}$ & GBM & Patient-derived GBM cells & [112] \\
\hline Not reported & GBM & $\begin{array}{l}\text { Patient-derived human } \\
\text { GBM cells }\end{array}$ & [113] \\
\hline NSG & GBM & $\begin{array}{c}\text { Patient-derived GBM } \\
\text { neuro-spheres }\end{array}$ & [114] \\
\hline \multirow{3}{*}{ Nude } & Glioma & $\begin{array}{l}\text { Patient-derived IDH mutant } \\
\text { glioma tissue }\end{array}$ & [115] \\
\hline & GBM & Patient-derived GBM tissue & {$[116,117]$} \\
\hline & GBM & Patient-derived GBM tissue & {$[28,118]$} \\
\hline \multirow[b]{2}{*}{ SCID } & IDH Mutant Glioma & $\begin{array}{c}\text { Patient-derived glioma } \\
\text { neuro-spheres }\end{array}$ & [119] \\
\hline & $\begin{array}{l}\text { IDH1 Mutated } \\
\text { Glioma }\end{array}$ & $\begin{array}{l}\text { GBM164, GBM196, and TB09 } \\
\text { IDH1 mutant glioma } \\
\text { PDX models }\end{array}$ & {$[120,121]$} \\
\hline
\end{tabular}

\section{Immunology Research in Xenograft Models}

Xenograft models have several benefits including low-cost and fast throughput [122]. A limitation of xenograft models is the required use of immune-deficient mice.

Immune-deficient mice used in xenograft models include nude mice, non-obese/diabetic mice (NOD), severe combined immunodeficient mice (SCID), and the combination NOD/SCID and NOD/SCID/interleukin IL2 receptor $\gamma_{\text {null }}$ (NSG) mice. The nude (athymic) mouse has a depleted population of T lymphocytes acquired through mutations in FOXP1 [123]. Nude mice have increased NK cell and macrophage activity as well as intact B cells, dendritic cells, and granulocytes [124]. Thus, while unable to characterize the lymphocyte mediated response, nude mice models can provide information on other immune cell interactions with the tumor [124]. Another common mouse utilized is the SCID mouse which lacks mature B and T lymphocytes [125]. NSG mice carry significant reductions in natural killer cell function in addition to $B$ and $T$ lymphocyte loss to reduce the innate and adaptive immune system for successful grafting of more immunogenic tumors [126]. These immunecompromised mice are necessary for the successful engraftment of tumors without risk of short-term rejection. Loss of the immune microenvironment limits study of tumor interaction with the immune system and testing of immune modulating agents [127,128]. Recent studies show that humanized mouse models may help to overcome this challenge [127].

Humanized mouse models are used to generate a mouse with a competent human immune system to study immune responses to anti-cancer immunotherapies [129]. They are created with NSG or NOD/SCID mice undergoing whole body irradiation followed by injection of human CD34+ hematopoietic stem cells intravascularly [124,130]. After 12 weeks of age, successful engraftment of the human immune system can be assessed with flow cytometry [129]. These humanized mice are then injected with patient derived tumor tissue to develop into humanized PDX models [129]. 
An alternate method to study immune systems in PDX models was proposed by Semenkow et al. (2017), who demonstrated that blocking T-cell co-activating signals with immune checkpoint inhibitors, abatacept and MR1, allowed for short term tumor development in orthotopic glioma murine models with intact immune systems [131]. Both models are cost- and time-intensive but add to the current and future understanding of immune modulation on tumorigenesis and progression.

\section{Syngeneic Models}

Syngeneic glioma rodent models have been generated via injection of the carcinogen ethyl nitrosourea into the placenta between the 15th and 18th day of murine pregnancy [22]. Additional syngeneic models, namely GL261 and CT-2A, were produced by intracranial injection of the carcinogen 3-methylcholantrene, leading to formation of tumors that resembled GBMs. Cell lines derived from these brain tumors can be used to create syngeneic allografts upon transplantation into naïve mice from the same genetic background [22,128,132]. Unlike xenograft models, syngeneic models utilize immune-competent animals. This allows the study of the interaction between the tumor and immune microenvironment, and the possibility of testing immunotherapies for cancer treatment. Like other models that are based on cell line propagation, the syngeneic mouse model is subject to genetic drift with long term propagation [22]. In addition, given that syngeneic models exclusively involve mouse tissue, they present challenges for translating findings to human cancer. Gliomas induced in mice through carcinogen exposure present as well-circumscribed tumors without infiltration into the surrounding brain parenchyma, which is not the typical growth pattern appreciated in human astrocytoma [22]. Therefore, these models do not fully recapitulate the morphological characteristics of human glioma [14,133].

\section{Genetically Engineered Mouse Models (GEMMs)}

GEMMs involve manipulation of the mouse genome to induce tumor formation [124]. By causing autochthonous tumors to form in mouse tissue, immune-competent mice can be utilized, a key advantage over xenograft models. The intact immune system and native tumor cytoarchitecture enable studies of the tumor microenvironment, while genetic engineering affords precise control over the molecular events leading to tumor formation, maintenance, and susceptibility to treatment [124]. Furthermore, GEMMs allow for the ability to activate relevant oncogenes at specific time points in tissue development, and they permit testing of potential therapeutic agents at various stages of tumorigenesis. These properties offer distinct advantages over PDX models, which are nearly universally derived from advanced human tumors.

GEMMs are frequently made with inbred mouse strains similar to those used in syngeneic models. The C57BL/ 6 mouse strain, established in the 1920s to study immune responses to cancer, has an increased NK cell activity and high cell-mediated immune response, but a weak antibody-mediated response [134]. By comparison, BALB/c mice have a stronger humoral immune reaction [135]. FVB/N mice (also known as friend virus B-type susceptibility), were created in the late 1970s from the Swiss N:GP mice (also known as the National Institute of Health general purpose mouse) [136]. In relation to BALB/c mice, FVB/N mice have been shown to respond with a greater Th2 bias; however, the immune status is poorly defined [137].

Historically, challenges with timing, sufficient tumor development, and inability to recapitulate the intra-tumoral heterogeneity of gliomas made it difficult to utilize GEMMs for in vivo glioma modeling [124]. Advancements in these GEMMs have created several modeling systems that better recapitulate human gliomas. These include development of the replication competent avian-like sarcoma virus and the corresponding avian tumor virus A (RCAS-tVA) system, the Cre-loxP system, and the sleeping beauty transposon system (Table 4). 
Table 4. Glioma genetically engineered mouse models (GEMMs).

\begin{tabular}{|c|c|c|c|}
\hline Mouse Species & Brain Tumor Modeled & Genetic Engineering & Reference \\
\hline C57BL/ 6 and $\mathrm{Tp} 53^{-/-}$ & GBM & PDGF $\beta$, p53 mutations & {$[138]$} \\
\hline \multirow{3}{*}{ C57BL/ 6} & Glioma & $\begin{array}{l}\text { Heterozygous TgGZT } 121, \text { KRAS }^{\mathrm{G} 12 \mathrm{D}} \text {, } \\
\text { GFAP-CreER, PP-CreER, NG2-CreER, } \\
\text { and Rosa26-tdTomato mice crossed } \\
\text { with mice with conditional PTEN, } \\
\text { p53, Rb1, or NF1 loss }\end{array}$ & [139] \\
\hline & Glioma & $\begin{array}{l}\text { Crossing of } \mathrm{NF}^{\text {flox }+} \text { mice with } \\
\mathrm{p} 53^{+/-} \text {mice and then crossed with } \\
\text { wild type F1 C57BL/ } 6 \text { mice }\end{array}$ & [140] \\
\hline & $\begin{array}{l}\text { High Grade } \\
\text { Astrocytoma }\end{array}$ & $\begin{array}{l}\text { RB, phosphate and tensin homolog } \\
\text { deleted on chromosome } 10 \text { (PTEN) } \\
\text { mutations }\end{array}$ & {$[141,142]$} \\
\hline $\begin{array}{l}\text { Crossed IDH1 and Nestin-Cre } \\
\text { transgenic mice }\end{array}$ & $\begin{array}{c}\text { IDH1 R132 } \\
\text { Mutated Glioma }\end{array}$ & Nestin-Cre remodeling system & [143] \\
\hline $\mathrm{FVB} / \mathrm{N}$ mice & Oligodendrocyte & $\begin{array}{c}\text { Ctv-a plasmid was transfected into an } \\
\text { immortalized oligodendroglia cell } \\
\text { line OLI-neu }\end{array}$ & [144] \\
\hline & GBM & K-Ras, Akt, Ink4a/Arf mutations & {$[145,146]$} \\
\hline $\begin{array}{l}\mathrm{FVB} / \mathrm{N}, \mathrm{C} 57 \mathrm{BL} / 6, \\
\mathrm{BALB} / \mathrm{C} \text {, and } 129\end{array}$ & GBM & $\begin{array}{c}\text { Platelet derived growh factor receptor } \\
\text { (PDGF) } \beta, \text { Ink4a/Arf, PTEN } \\
\text { mutations }\end{array}$ & [147] \\
\hline Gtv-a $\mathrm{Arf}^{-/-}$ & $\begin{array}{l}\text { High Grade } \\
\text { Glioma }\end{array}$ & Induction with RCAS-PDGF-B & [148] \\
\hline \multirow{2}{*}{ INK $4 \mathrm{a}^{+/+}$and INK4a ${ }^{-/-}$} & GBM & PDGF $\beta$ & [149] \\
\hline & IDH1 mutant and wildtype gliomas & PDGF, Tp53, and IDH1 mutations & [150] \\
\hline $\begin{array}{l}\text { MUT3 (Mice with mixed } \\
\text { genetic background of } \\
\text { C57BL/6, Sv129 and B6/CBA) }\end{array}$ & De novo GBM & $\begin{array}{l}\text { Introduced PTEN and p53 flexed } \\
\text { alleles into MUT3 mice }\end{array}$ & [151] \\
\hline \multirow{4}{*}{ Not Reported } & $\begin{array}{l}\text { High Grade } \\
\text { Glioma }\end{array}$ & K-Ras, p53, Ink4a/Arf mutations & [152] \\
\hline & GBM & $\begin{array}{l}\text { EGFRvIII, Ink4a/Arf, PTEN } \\
\text { mutations }\end{array}$ & [153] \\
\hline & GBM & PDGF $\beta$ mutation & {$[154]$} \\
\hline & $\begin{array}{l}\text { Lower- and } \\
\text { Higher-Grade } \\
\text { Gliomas }\end{array}$ & $\begin{array}{c}\text { Neuroblastoma RAS (NRAS) G12V } \\
\text { and shp53 Sleeping beauty plasmids } \\
\text { with or without shATRX and } \\
\text { IDH1 }{ }^{\text {R132H }}\end{array}$ & [155] \\
\hline RasB8 & $\begin{array}{l}\text { High Grade } \\
\text { Glioma }\end{array}$ & EGFRvIII and $\mathrm{V}^{12}$ Ras mutation & [156] \\
\hline Rosa26-SB11 & $\begin{array}{l}\text { High Grade } \\
\text { Glioma }\end{array}$ & $\mathrm{T} 2 /$ onc mutagenic transposon & [157] \\
\hline $\begin{array}{l}\text { GFAP-Cre transgenic mice } \\
\text { maintained with C57BL/ } 6 \text { and } \\
\text { crossed with Tp53-/- mice }\end{array}$ & $\begin{array}{l}\text { High Grade } \\
\text { Glioma }\end{array}$ & H-Ras, AKT and Tp53 mutations & [158] \\
\hline
\end{tabular}

\subsection{Somatic Gene Delivery Models}

The RCAS-tVA system allows for oncogenes to be transferred to cells that express the tVA receptor using a cell type-specific promoter [22]. Importantly, the avian virus used in this system does not replicate in mammalian cells. Therefore, the interaction between 
induced tumor cells and healthy cells remains intact and can be evaluated without the potentially confounding effects of viral propagation [22,159]. Genetic mutations arising in single cells and cells selectively undergoing clonal expansion can be demonstrated by this model [160]. Tissue-specific promoters can be used to selectively introduce oncogenes into nestin-positive neural stem and progenitor cells (Ntv-a), glial fibrillary acidic protein (GFAP) -positive glial cells (Gtv-a), or CNPase-positive oligo-dendroglial cells (Ctv-a), thereby enabling studies of the tumor cell of origin in glioma GEMMs [159].

Holland and Varmus (1997) were the first to use an RCAS-tVA transgenic mouse model to demonstrate induction, proliferation, and migration of glial cells with $\beta$-FGF [159-161]. They also subsequently showed that EGFR mutations in murine glial cells induce lesions that are similar to human gliomas [162]. EGFR-induced gliomas also form in transgenic mice with a INK4a-ARF tumor suppressor locus disruption [162].

While the RCAS-tVA system is limited by the vector capacity of the RCAS virus, other viruses have been used for somatic gene transfer and GEMM production, including adeno-associated viruses (AAVs), adenoviruses, and lentiviruses [22,160]. Marumoto et al. (2009) successfully utilized a Cre-loxP controlled lentiviral vector expressing activated Harvey-Ras and AKT to recapitulate simultaneous activation of oncogenes in a few cells to initiate the formation of grade III and IV gliomas in immune-competent adult mice [158]. The advantage of these viruses in comparison to the RCAS virus is the ability to infect both dividing and non-dividing cells [159].

\subsection{Conditional Allele-Specific Models}

The Cre-loxP system utilizes the Cre recombinase enzyme to induce recombination between two loxP recognition sites [22]. Conditional models involve breeding a tissuespecific transgenic Cre recombinase mouse with a mouse in which a gene (or genes) of interest has been flanked with loxP sites through a knock-in approach [163]. An inducible Cre-loxP system is created by placing Cre protein activity or gene expression under control of tamoxifen (Cre-ER) or tetracycline (Tet-On/Off) [164]. Cre-loxP systems offer highly efficient genetic modification and have been utilized to create mice that develop GBMs through the introduction of EGFRvIII mutations [22,163]. Cre recombinase expression cassettes can be placed under the control of brain-specific promoters, such as nestin or GFAP, to achieve cell type-specific genetic engineering $[165,166]$.

Cre-loxP systems have been utilized to evaluate the relationship between NF1 and glioma formation. C57BL/ 6 mice with NF1 mutations inbred with C57BL/ 6 mice with TP53 mutations developed malignant glial neoplasms of the central and peripheral nervous system [167]. Zhu et al. (2005) demonstrated that mice with NF1 and p53 mutations develop WHO grade II gliomas that progress to anaplastic astrocytoma and GBMs $[140,167]$.

\subsection{Transposon/Transposase Models}

The sleeping beauty system can be used to identify genetic drivers in animal models in an unbiased manner [22]. This system is thus important in understanding gliomagenesis [22]. Bender et al. (2010) utilized a T2/onc transposon with a constitutively active sleeping beauty transposase to create a high grade astrocytoma. The resulting gliomas displayed an invasive phenotype and expressed GFAP and S100 markers, which are characteristic of human brain tumors, indicating that this is an effective system to model glioma formation [157].

\section{Special Consideration for IDH1/2 Mutations}

Overall, approximately $80 \%$ of lower-grade gliomas and secondary glioblastomas harbor an IDH1 or IDH2 mutation, thus supporting the inclusion of this class of mutations in mouse models of these glioma subtypes [155]. The IDH1-R132H mutation is by far the most common IDH1 or IDH2 mutation observed in glioma. IDH1/2 mutant oncoproteins harbor point mutations in arginine residues that line these enzymes' active sites. Wild-type IDH enzymes normally convert isocitrate to alpha-ketoglutarate $(\alpha-K G)$, whereas IDH mu- 
tant oncoproteins gain the neo-morphic ability to convert $\alpha$-KG into D-2-hydroxyglutarate (D-2-HG), a compound normally found in small intracellular quantities [168]. High levels of D-2-HG competitively inhibit $\alpha$-KG-dependent enzymes, leading to widespread epigenetic and metabolic reprogramming [169]. Importantly, although low grade gliomas with IDH mutations carry a relatively favorable prognosis, these tumors inexorably progress to high grade glioma and are universally fatal. Thus, creating accurate mouse models of IDH mutant glioma to study the unique pathobiology of these tumors is imperative.

Philip et al. (2018) utilized an RCAS-Ntv-a system to create an IDH1 mutant glioma model by expressing the IDH1-R132H oncoprotein and platelet derived growth factor receptor A (PDGFRA), and simultaneously silencing CDKN2A, alpha thalassemia/mental retardation syndrome $x$-linked (ATRX), and PTEN [170]. Heterotopic and orthotopic IDH1 mutant glioma xenografts are also utilized to model this disease state [22]. Borodovsky et al. (2015) utilized fresh patient tissue to create a subcutaneous IDH1 mutant tumor that was serially propagated [168]. Later, dissociated cells were implanted into nude mice orthotopically and displayed IDH1 mutant anaplastic astrocytoma formation leading to the creation of the JHH-273 murine model [168]. Orthotopic xenograft models of IDH1 mutant GBM, including the MGG152 model, have also been used to identify new therapeutic targets in this disease, including the discovery of NAD+ biosynthesis as a novel metabolic vulnerability conferred by IDH oncogenes [171].

Establishing new models of other IDH mutant glioma subtypes is also important for pre-clinical testing of new therapeutic strategies. The TS603 subcutaneous xenograft model of oligodendroglioma (featuring pathognomonic codeletion of $1 p / 19 q$ chromosome arms and mutation of IDH1) has been utilized to test the antitumor efficacy of the mutant IDH1 inhibitor AGI-5198 [172]. Importantly, AGI-5198 blocked growth of TS603 xenografts, thus paving the way for clinical trials of mutant IDH inhibitors in glioma [172]. Schumacher et al. (2014) utilized a humanized murine model to demonstrate that a mutant IDHspecific vaccine induces interferon gamma-producing T-cells that target IDH1 mutant tumor cells $[173,174]$. There are currently on-going clinical trials to assess if these therapeutic approaches will be effective treatment strategies for patients with low grade gliomas [174].

Much like IDH1/2 mutations, improved understanding of epigenetic dysregulation in glioma has led to the discovery of mutations encoding a lysine to methionine substitution at position 27 in histone $\mathrm{H} 3$ (H3K27M), which leads to the formation of high-grade gliomas, especially diffuse midline gliomas in children [175-177]. The introduction of newly identified mutations into murine models of glioma is expected to open new avenues for preclinical investigation of novel glioma onco-genotypes in future studies.

\section{Conclusions}

Glioma animal models offer substantive advantages over in vitro two-dimensional glioma cell cultures as they better recapitulate the genetic, morphologic, and immunologic characteristics of human tumors. Since the development of the first murine cancer xenograft model 70 years ago, there have been many advances, including the creation of PDXs and GEMMs. These developments have allowed for the creation of faithful glioma models to study the genetic and molecular changes driving glioma-genesis, immunologic tumor recognition, and therapeutic response. The development of innovative new glioma murine models provides opportunities to study the process of glioma-genesis in greater detail and to evaluate the safety and efficacy of experimental treatments more accurately in the preclinical setting.

Author Contributions: Conceptualization, S.K.M., K.G.A. Data curation C.E.B. and W.H.H. Writingoriginal draft preparation, C.E.B. and W.H.H. Writing review and editing, C.E.B., W.H.H., J.I.T., D.D.S., T.Y.E.A., T.E.R., S.K.M., K.G.A. All authors have read and agreed to the published version of the manuscript.

Funding: This research was funded by the Eugene P. Frenkel, M.D. Endowed Scholar Program (K.G.A), Cancer Prevention and Research Institute of Texas grant number RR190034 (S.K.M.), and 
National Cancer Institute grant number K22CA237752 (S.K.M). C.E.B. is supported by a PhysicianScientist Institutional Award from the Burroughs Wellcome Fund.

Institutional Review Board Statement: Not applicable.

Informed Consent Statement: Not applicable.

Data Availability Statement: Not applicable.

Acknowledgments: The authors would like to thank Melissa Logies for the illustration of Figure 1.

Conflicts of Interest: The authors declare no conflict of interest. The funders had no role in the design of the study; in the collection, analyses, or interpretation of data; in the writing of the manuscript, or in the decision to publish the results.

\section{References}

1. Omuro, A.; DeAngelis, L.M. Glioblastoma and other malignant gliomas: A clinical review. JAMA 2013, 310, 1842-1850. [CrossRef] [PubMed]

2. Chinwalla, A.T.; Cook, L.L.; Delehaunty, K.D.; Fewell, G.A.; Fulton, L.A.; Fulton, R.S.; Graves, T.A.; Hillier, L.W.; Mardis, E.R.; McPherson, J.D.; et al. Initial sequencing and comparative analysis of the mouse genome. Nature 2002, 420, 520-562. [CrossRef]

3. Noorani, I. Genetically Engineered Mouse Models of Gliomas: Technological Developments for Translational Discoveries. Cancers 2019, 11, 1335. [CrossRef]

4. Comprehensive genomic characterization defines human glioblastoma genes and core pathways. Nature 2008, 455, 1061-1068. [CrossRef]

5. Chen, R.; Smith-Cohn, M.; Cohen, A.L.; Colman, H. Glioma Subclassifications and Their Clinical Significance. Neurotherapeutics 2017, 14, 284-297. [CrossRef]

6. Robertson, F.L.; Marques-Torrejon, M.A.; Morrison, G.M.; Pollard, S.M. Experimental models and tools to tackle glioblastoma. Dis. Model. Mech. 2019, 12. [CrossRef]

7. Stylli, S.S.; Luwor, R.B.; Ware, T.M.; Tan, F.; Kaye, A.H. Mouse models of glioma. J. Clin. Neurosci. 2015, 22, 619-626. [CrossRef]

8. Imagi, S. Experimental study on heterotransplantation of Tanaka's rabbit-hepatoma and intestinal cancer into guinea pigs. Gan 1950, 41, 231-233.

9. Toolan, H.W. Growth of human tumors in cortisone-treated laboratory animals: The possibility of obtaining permanently transplantable human tumors. Cancer Res. 1953, 13, 389-394.

10. Povlsen, C.O.; Spang-Thomsen, M.; Rygaard, J.; Visfeldt, J. Heterotransplantation of human malignant tumours to athymic nude mice. In Immunodeficient Animals for Cancer Research; Sparrow, S., Ed.; Palgrave Macmillan: London, UK, 1980; pp. 95-103. [CrossRef]

11. Okada, S.; Vaeteewoottacharn, K.; Kariya, R. Application of Highly Immunocompromised Mice for the Establishment of Patient-Derived Xenograft (PDX) Models. Cells 2019, 8, 889. [CrossRef]

12. Talmadge, J.E.; Singh, R.K.; Fidler, I.J.; Raz, A. Murine models to evaluate novel and conventional therapeutic strategies for cancer. Am. J. Pathol. 2007, 170, 793-804. [CrossRef]

13. Oh, T.; Fakurnejad, S.; Sayegh, E.T.; Clark, A.J.; Ivan, M.E.; Sun, M.Z.; Safaee, M.; Bloch, O.; James, C.D.; Parsa, A.T. Immunocompetent murine models for the study of glioblastoma immunotherapy. J. Transl. Med. 2014, 12, 107. [CrossRef]

14. Chulpanova, D.S.; Kitaeva, K.V.; Rutland, C.S.; Rizvanov, A.A.; Solovyeva, V.V. Mouse Tumor Models for Advanced Cancer Immunotherapy. Int. J. Mol. Sci. 2020, 21, 4118. [CrossRef]

15. Smith, H.W.; Muller, W.J. Transgenic mouse models-A seminal breakthrough in oncogene research. Cold Spring Harb. Protoc. 2013, 2013, 1099-1108. [CrossRef]

16. Hanahan, D.; Wagner, E.F.; Palmiter, R.D. The origins of oncomice: A history of the first transgenic mice genetically engineered to develop cancer. Genes Dev. 2007, 21, 2258-2270. [CrossRef]

17. Adams, J.M.; Harris, A.W.; Pinkert, C.A.; Corcoran, L.M.; Alexander, W.S.; Cory, S.; Palmiter, R.D.; Brinster, R.L. The c-myc oncogene driven by immunoglobulin enhancers induces lymphoid malignancy in transgenic mice. Nature 1985, 318, 533-538. [CrossRef]

18. Brinster, R.L.; Chen, H.Y.; Messing, A.; van Dyke, T.; Levine, A.J.; Palmiter, R.D. Transgenic mice harboring SV40 T-antigen genes develop characteristic brain tumors. Cell 1984, 37, 367-379. [CrossRef]

19. Stewart, T.A.; Pattengale, P.K.; Leder, P. Spontaneous mammary adenocarcinomas in transgenic mice that carry and express $\mathrm{MTV} /$ myc fusion genes. Cell 1984, 38, 627-637. [CrossRef]

20. Gu, H.; Zou, Y.R.; Rajewsky, K. Independent control of immunoglobulin switch recombination at individual switch regions evidenced through Cre-loxP-mediated gene targeting. Cell 1993, 73, 1155-1164. [CrossRef]

21. Jung, S.; Rajewsky, K.; Radbruch, A. Shutdown of class switch recombination by deletion of a switch region control element. Science 1993, 259, 984-987. [CrossRef]

22. Akter, F.; Simon, B.; de Boer, N.L.; Redjal, N.; Wakimoto, H.; Shah, K. Pre-clinical tumor models of primary brain tumors: Challenges and opportunities. Biochim. Et Biophys. Acta. Rev. Cancer 2021, 1875, 188458. [CrossRef] 
23. Brighi, C.; Reid, L.; Genovesi, L.A.; Kojic, M.; Millar, A.; Bruce, Z.; White, A.L.; Day, B.W.; Rose, S.; Whittaker, A.K.; et al. Comparative study of preclinical mouse models of high-grade glioma for nanomedicine research: The importance of reproducing blood-brain barrier heterogeneity. Theranostics 2020, 10, 6361-6371. [CrossRef]

24. Frese, K.K.; Tuveson, D.A. Maximizing mouse cancer models. Nat. Rev. Cancer 2007, 7, 645-658. [CrossRef]

25. Yi, Y.; Hsieh, I.Y.; Huang, X.; Li, J.; Zhao, W. Glioblastoma Stem-Like Cells: Characteristics, Microenvironment, and Therapy. Front. Pharm. 2016, 7, 477. [CrossRef]

26. Adhikari, B.; Li, J.; Brandel, M.G.; Futalan, D.; Akers, J.; Deming, T.; Chen, C.C.; Carter, B.S. The use of TMZ embedded hydrogels for the treatment of orthotopic human glioma xenografts. J. Clin. Neurosci. 2017, 45, 288-292. [CrossRef]

27. Kaye, A.H.; Morstyn, G.; Gardner, I.; Pyke, K. Development of a xenograft glioma model in mouse brain. Cancer Res. 1986, 46, 1367-1373. [PubMed]

28. Irtenkauf, S.M.; Sobiechowski, S.; Hasselbach, L.A.; Nelson, K.K.; Transou, A.D.; Carlton, E.T.; Mikkelsen, T.; deCarvalho, A.C. Optimization of Glioblastoma Mouse Orthotopic Xenograft Models for Translational Research. Comp. Med. 2017, 67, 300-314.

29. Miner, M.W.; Liljenbäck, H.; Virta, J.; Merisaari, J.; Oikonen, V.; Westermarck, J.; Li, X.G.; Roivainen, A. (2S, 4R)-4[(18)F]Fluoroglutamine for In vivo PET Imaging of Glioma Xenografts in Mice: An Evaluation of Multiple Pharmacokinetic Models. Mol. Imaging Biol. 2020, 22, 969-978. [CrossRef]

30. Pellegatta, S.; Poliani, P.L.; Corno, D.; Menghi, F.; Ghielmetti, F.; Suarez-Merino, B.; Caldera, V.; Nava, S.; Ravanini, M.; Facchetti, F.; et al. Neurospheres enriched in cancer stem-like cells are highly effective in eliciting a dendritic cell-mediated immune response against malignant gliomas. Cancer Res. 2006, 66, 10247-10252. [CrossRef]

31. Pellegatta, S.; Finocchiaro, G. Dendritic cell vaccines for cancer stem cells. Methods Mol. Biol. 2009, 568, 233-247. [CrossRef]

32. Wagemakers, M.; van der Wal, G.E.; Cuberes, R.; Alvarez, I.; Andrés, E.M.; Buxens, J.; Vela, J.M.; Moorlag, H.; Mooij, J.J.; Molema, G. COX-2 Inhibition Combined with Radiation Reduces Orthotopic Glioma Outgrowth by Targeting the Tumor Vasculature. Transl. Oncol. 2009, 2, 1-7. [CrossRef] [PubMed]

33. Markovic, D.S.; Vinnakota, K.; van Rooijen, N.; Kiwit, J.; Synowitz, M.; Glass, R.; Kettenmann, H. Minocycline reduces glioma expansion and invasion by attenuating microglial MT1-MMP expression. Brain Behav. Immun. 2011, 25, 624-628. [CrossRef]

34. Daga, A.; Orengo, A.M.; Gangemi, R.M.; Marubbi, D.; Perera, M.; Comes, A.; Ferrini, S.; Corte, G. Glioma immunotherapy by IL-21 gene-modified cells or by recombinant IL-21 involves antibody responses. Int. J. Cancer 2007, 121, 1756-1763. [CrossRef]

35. Cantini, G.; Pisati, F.; Mastropietro, A.; Frattini, V.; Iwakura, Y.; Finocchiaro, G.; Pellegatta, S. A critical role for regulatory T cells in driving cytokine profiles of Th17 cells and their modulation of glioma microenvironment. Cancer Immunol. Immunother. 2011, 60, 1739-1750. [CrossRef]

36. Yamazoe, T.; Koizumi, S.; Yamasaki, T.; Amano, S.; Tokuyama, T.; Namba, H. Potent tumor tropism of induced pluripotent stem cells and induced pluripotent stem cell-derived neural stem cells in the mouse intracerebral glioma model. Int. J. Oncol. 2015, 46, 147-152. [CrossRef]

37. Aguilar-Morante, D.; Cortes-Canteli, M.; Sanz-Sancristobal, M.; Santos, A.; Perez-Castillo, A. Decreased CCAAT/enhancer binding protein $\beta$ expression inhibits the growth of glioblastoma cells. Neuroscience 2011, 176, 110-119. [CrossRef]

38. Hülper, P.; Schulz-Schaeffer, W.; Dullin, C.; Hoffmann, P.; Harper, J.; Kurtzberg, L.; Lonning, S.; Kugler, W.; Lakomek, M.; Erdlenbruch, B. Tumor localization of an anti-TGF- $\beta$ antibody and its effects on gliomas. Int. J. Oncol. 2011, 38, 51-59. [CrossRef]

39. Madala, H.R.; Punganuru, S.R.; Ali-Osman, F.; Zhang, R.; Srivenugopal, K.S. Brain- and brain tumor-penetrating disulfiram nanoparticles: Sequence of cytotoxic events and efficacy in human glioma cell lines and intracranial xenografts. Oncotarget 2018, 9, 3459-3482. [CrossRef]

40. Larsson, S.; Wenger, A.; Dósa, S.; Sabel, M.; Kling, T.; Carén, H. Cell line-based xenograft mouse model of paediatric glioma stem cells mirrors the clinical course of the patient. Carcinogenesis 2018, 39, 1304-1309. [CrossRef]

41. Weissenberger, J.; Priester, M.; Bernreuther, C.; Rakel, S.; Glatzel, M.; Seifert, V.; Kögel, D. Dietary curcumin attenuates glioma growth in a syngeneic mouse model by inhibition of the JAK1,2/STAT3 signaling pathway. Clin. Cancer Res. Off. J. Am. Assoc. Cancer Res. 2010, 16, 5781-5795. [CrossRef]

42. Kiviniemi, A.; Gardberg, M.; Autio, A.; Li, X.G.; Heuser, V.D.; Liljenback, H.; Kakela, M.; Sipila, H.; Kurkipuro, J.; Yla-Herttuala, S.; et al. Feasibility of experimental BT4C glioma models for somatostatin receptor 2-targeted therapies. Acta Oncol. 2014, 53, 1125-1134. [CrossRef] [PubMed]

43. Zhang, L.; Zhu, S.; Qian, L.; Pei, Y.; Qiu, Y.; Jiang, Y. RGD-modified PEG-PAMAM-DOX conjugates: In vitro and in vivo studies for glioma. Eur. J. Pharm. Biopharm. Off. J. Arb. Fur Pharm. Verfahr. EV 2011, 79, 232-240. [CrossRef]

44. Luchman, H.A.; Stechishin, O.D.; Dang, N.H.; Blough, M.D.; Chesnelong, C.; Kelly, J.J.; Nguyen, S.A.; Chan, J.A.; Weljie, A.M.; Cairncross, J.G.; et al. An in vivo patient-derived model of endogenous IDH1-mutant glioma. Neuro Oncol. $2012,14,184-191$. [CrossRef] [PubMed]

45. Fareh, M.; Turchi, L.; Virolle, V.; Debruyne, D.; Almairac, F.; de-la-Forest Divonne, S.; Paquis, P.; Preynat-Seauve, O.; Krause, K.H.; Chneiweiss, H.; et al. The miR 302-367 cluster drastically affects self-renewal and infiltration properties of glioma-initiating cells through CXCR4 repression and consequent disruption of the SHH-GLI-NANOG network. Cell Death Differ. 2012, 19, 232-244. [CrossRef] [PubMed]

46. Jandial, R.; Neman, J.; Lim, P.P.; Tamae, D.; Kowolik, C.M.; Wuenschell, G.E.; Shuck, S.C.; Ciminera, A.K.; De Jesus, L.R.; Ouyang, C.; et al. Inhibition of GLO1 in Glioblastoma Multiforme Increases DNA-AGEs, Stimulates RAGE Expression, and Inhibits Brain Tumor Growth in Orthotopic Mouse Models. Int. J. Mol. Sci. 2018, 19, 406. [CrossRef] 
47. Hlavaty, J.; Jandl, G.; Liszt, M.; Petznek, H.; König-Schuster, M.; Sedlak, J.; Egerbacher, M.; Weissenberger, J.; Salmons, B.; Günzburg, W.H.; et al. Comparative evaluation of preclinical in vivo models for the assessment of replicating retroviral vectors for the treatment of glioblastoma. J. Neurooncol. 2011, 102, 59-69. [CrossRef]

48. Ni, X.R.; Zhao, Y.Y.; Cai, H.P.; Yu, Z.H.; Wang, J.; Chen, F.R.; Yu, Y.J.; Feng, G.K.; Chen, Z.P. Transferrin receptor 1 targeted optical imaging for identifying glioma margin in mouse models. J. Neurooncol. 2020, 148, 245-258. [CrossRef]

49. Beck, S.; Jin, X.; Yin, J.; Kim, S.H.; Lee, N.K.; Oh, S.Y.; Jin, X.; Kim, M.K.; Kim, E.B.; Son, J.S.; et al. Identification of a peptide that interacts with Nestin protein expressed in brain cancer stem cells. Biomaterials 2011, 32, 8518-8528. [CrossRef] [PubMed]

50. Nicolaides, T.P.; Li, H.; Solomon, D.A.; Hariono, S.; Hashizume, R.; Barkovich, K.; Baker, S.J.; Paugh, B.S.; Jones, C.; Forshew, T.; et al. Targeted therapy for BRAFV600E malignant astrocytoma. Clin. Cancer Res. Off. J. Am. Assoc. Cancer Res. 2011, 17, 7595-7604. [CrossRef]

51. Santagata, S.; Xu, Y.M.; Wijeratne, E.M.; Kontnik, R.; Rooney, C.; Perley, C.C.; Kwon, H.; Clardy, J.; Kesari, S.; Whitesell, L.; et al. Using the heat-shock response to discover anticancer compounds that target protein homeostasis. ACS Chem. Biol. 2012, 7, 340-349. [CrossRef]

52. Moroz, M.A.; Huang, R.; Kochetkov, T.; Shi, W.; Thaler, H.; de Stanchina, E.; Gamez, I.; Ryan, R.P.; Blasberg, R.G. Comparison of corticotropin-releasing factor, dexamethasone, and temozolomide: Treatment efficacy and toxicity in U87 and C6 intracranial gliomas. Clin. Cancer Res. Off. J. Am. Assoc. Cancer Res. 2011, 17, 3282-3292. [CrossRef]

53. Burden-Gulley, S.M.; Qutaish, M.Q.; Sullivant, K.E.; Lu, H.; Wang, J.; Craig, S.E.; Basilion, J.P.; Wilson, D.L.; Brady-Kalnay, S.M. Novel cryo-imaging of the glioma tumor microenvironment reveals migration and dispersal pathways in vivid three-dimensional detail. Cancer Res. 2011, 71, 5932-5940. [CrossRef]

54. Navis, A.C.; Hamans, B.C.; Claes, A.; Heerschap, A.; Jeuken, J.W.; Wesseling, P.; Leenders, W.P. Effects of targeting the VEGF and PDGF pathways in diffuse orthotopic glioma models. J. Pathol. 2011, 223, 626-634. [CrossRef]

55. Bai, R.Y.; Staedtke, V.; Aprhys, C.M.; Gallia, G.L.; Riggins, G.J. Antiparasitic mebendazole shows survival benefit in 2 preclinical models of glioblastoma multiforme. Neuro Oncol. 2011, 13, 974-982. [CrossRef]

56. Emdad, L.; Sarkar, D.; Lee, S.G.; Su, Z.Z.; Yoo, B.K.; Dash, R.; Yacoub, A.; Fuller, C.E.; Shah, K.; Dent, P.; et al. Astrocyte elevated gene-1: A novel target for human glioma therapy. Mol. Cancer Ther. 2010, 9, 79-88. [CrossRef]

57. Jamal, M.; Rath, B.H.; Williams, E.S.; Camphausen, K.; Tofilon, P.J. Microenvironmental regulation of glioblastoma radioresponse. Clin. Cancer Res. Off. J. Am. Assoc. Cancer Res. 2010, 16, 6049-6059. [CrossRef]

58. Jamal, M.; Rath, B.H.; Tsang, P.S.; Camphausen, K.; Tofilon, P.J. The brain microenvironment preferentially enhances the radioresistance of CD133(+) glioblastoma stem-like cells. Neoplasia 2012, 14, 150-158. [CrossRef] [PubMed]

59. Marian, C.O.; Cho, S.K.; McEllin, B.M.; Maher, E.A.; Hatanpaa, K.J.; Madden, C.J.; Mickey, B.E.; Wright, W.E.; Shay, J.W.; Bachoo, R.M. The telomerase antagonist, imetelstat, efficiently targets glioblastoma tumor-initiating cells leading to decreased proliferation and tumor growth. Clin. Cancer Res. Off. J. Am. Assoc. Cancer Res. 2010, 16, 154-163. [CrossRef]

60. Bruyère, C.; Abeloos, L.; Lamoral-Theys, D.; Senetta, R.; Mathieu, V.; Le Mercier, M.; Kast, R.E.; Cassoni, P.; Vandenbussche, G.; Kiss, R.; et al. Temozolomide modifies caveolin-1 expression in experimental malignant gliomas in vitro and in vivo. Transl. Oncol. 2011, 4, 92-100. [CrossRef]

61. Zhu, H.; Li, J.T.; Zheng, F.; Martin, E.; Kots, A.Y.; Krumenacker, J.S.; Choi, B.K.; McCutcheon, I.E.; Weisbrodt, N.; Bögler, O.; et al. Restoring soluble guanylyl cyclase expression and function blocks the aggressive course of glioma. Mol. Pharmacol. 2011, 80, 1076-1084. [CrossRef]

62. Bruyère, C.; Madonna, S.; Van Goietsenoven, G.; Mathieu, V.; Dessolin, J.; Kraus, J.L.; Lefranc, F.; Kiss, R. JLK1486, a Bis 8-Hydroxyquinoline-Substituted Benzylamine, Displays Cytostatic Effects in Experimental Gliomas through MyT1 and STAT1 Activation and, to a Lesser Extent, PPAR $\gamma$ Activation. Transl. Oncol. 2011, 4, 126-137. [CrossRef]

63. Qutaish, M.Q.; Sullivant, K.E.; Burden-Gulley, S.M.; Lu, H.; Roy, D.; Wang, J.; Basilion, J.P.; Brady-Kalnay, S.M.; Wilson, D.L. Cryo-image analysis of tumor cell migration, invasion, and dispersal in a mouse xenograft model of human glioblastoma multiforme. Mol. Imaging Biol. 2012, 14, 572-583. [CrossRef]

64. Tabatabai, G.; Frank, B.; Wick, A.; Lemke, D.; von Kürthy, G.; Obermüller, U.; Heckl, S.; Christ, G.; Weller, M.; Wick, W. Synergistic antiglioma activity of radiotherapy and enzastaurin. Ann. Neurol. 2007, 61, 153-161. [CrossRef]

65. Dong, J.; Zhou, G.; Tang, D.; Chen, Y.; Cui, B.; Dai, X.; Zhang, J.; Lan, Q.; Huang, Q. Local delivery of slow-releasing temozolomide microspheres inhibits intracranial xenograft glioma growth. J. Cancer Res. Clin. Oncol. 2012, 138, 2079-2084. [CrossRef]

66. Le Calvé, B.; Rynkowski, M.; Le Mercier, M.; Bruyère, C.; Lonez, C.; Gras, T.; Haibe-Kains, B.; Bontempi, G.; Decaestecker, C.; Ruysschaert, J.M.; et al. Long-term in vitro treatment of human glioblastoma cells with temozolomide increases resistance in vivo through up-regulation of GLUT transporter and aldo-keto reductase enzyme AKR1C expression. Neoplasia 2010, 12, 727-739. [CrossRef]

67. Najbauer, J.; Huszthy, P.C.; Barish, M.E.; Garcia, E.; Metz, M.Z.; Myers, S.M.; Gutova, M.; Frank, R.T.; Miletic, H.; Kendall, S.E.; et al. Cellular host responses to gliomas. PLoS ONE 2012, 7, e35150. [CrossRef] [PubMed]

68. Staquicini, F.I.; Ozawa, M.G.; Moya, C.A.; Driessen, W.H.; Barbu, E.M.; Nishimori, H.; Soghomonyan, S.; Flores, L.G., 2nd; Liang, X.; Paolillo, V.; et al. Systemic combinatorial peptide selection yields a non-canonical iron-mimicry mechanism for targeting tumors in a mouse model of human glioblastoma. J. Clin. Investig. 2011, 121, 161-173. [CrossRef]

69. Schauff, A.K.; Kim, E.L.; Leppert, J.; Nadrowitz, R.; Wuestenberg, R.; Brockmann, M.A.; Giese, A. Inhibition of invasion-associated thromboxane synthase sensitizes experimental gliomas to gamma-radiation. J. Neurooncol. 2009, 91, 241-249. [CrossRef] [PubMed] 
70. McGee, M.C.; Hamner, J.B.; Williams, R.F.; Rosati, S.F.; Sims, T.L.; Ng, C.Y.; Gaber, M.W.; Calabrese, C.; Wu, J.; Nathwani, A.C.; et al. Improved intratumoral oxygenation through vascular normalization increases glioma sensitivity to ionizing radiation. Int. J. Radiat. Oncol. Biol. Phys. 2010, 76, 1537-1545. [CrossRef]

71. Kim, Y.; Kim, K.H.; Lee, J.; Lee, Y.A.; Kim, M.; Lee, S.J.; Park, K.; Yang, H.; Jin, J.; Joo, K.M.; et al. Wnt activation is implicated in glioblastoma radioresistance. Lab. Investig. A J. Tech. Methods Pathol. 2012, 92, 466-473. [CrossRef] [PubMed]

72. Chaponis, D.; Barnes, J.W.; Dellagatta, J.L.; Kesari, S.; Fast, E.; Sauvageot, C.; Panagrahy, D.; Greene, E.R.; Ramakrishna, N.; Wen, P.Y.; et al. Lonafarnib (SCH66336) improves the activity of temozolomide and radiation for orthotopic malignant gliomas. $J$. Neurooncol. 2011, 104, 179-189. [CrossRef] [PubMed]

73. Chen, T.C.; Wang, W.; Golden, E.B.; Thomas, S.; Sivakumar, W.; Hofman, F.M.; Louie, S.G.; Schönthal, A.H. Green tea epigallocatechin gallate enhances therapeutic efficacy of temozolomide in orthotopic mouse glioblastoma models. Cancer Lett. 2011, 302, 100-108. [CrossRef]

74. Matsumura, Y. Preclinical and clinical studies of NK012, an SN-38-incorporating polymeric micelles, which is designed based on EPR effect. Adv. Drug Deliv. Rev. 2011, 63, 184-192. [CrossRef]

75. Redjal, N.; Chan, J.A.; Segal, R.A.; Kung, A.L. CXCR4 inhibition synergizes with cytotoxic chemotherapy in gliomas. Clin. Cancer Res. Off. J. Am. Assoc. Cancer Res. 2006, 12, 6765-6771. [CrossRef] [PubMed]

76. Nuthalapati, S.; Zhou, Q.; Guo, P.; Lv, H.; Cosenza, S.; Reddy, M.V.; Reddy, E.P.; Gallo, J.M. Preclinical pharmacokinetic and pharmacodynamic evaluation of novel anticancer agents, ON01910.Na (Rigosertib, Estybon ${ }^{\mathrm{TM}}$ ) and ON013105, for brain tumor chemotherapy. Pharm. Res. 2012, 29, 2499-2511. [CrossRef]

77. Lamfers, M.L.; Idema, S.; Bosscher, L.; Heukelom, S.; Moeniralm, S.; van der Meulen-Muileman, I.H.; Overmeer, R.M.; van der Valk, P.; van Beusechem, V.W.; Gerritsen, W.R.; et al. Differential effects of combined Ad5- delta 24RGD and radiation therapy in in vitro versus in vivo models of malignant glioma. Clin. Cancer Res. Off. J. Am. Assoc. Cancer Res. 2007, 13, 7451-7458. [CrossRef] [PubMed]

78. Bertrand, Y.; Currie, J.C.; Poirier, J.; Demeule, M.; Abulrob, A.; Fatehi, D.; Stanimirovic, D.; Sartelet, H.; Castaigne, J.P.; Béliveau, R. Influence of glioma tumour microenvironment on the transport of ANG1005 via low-density lipoprotein receptor-related protein 1. Br. J. Cancer 2011, 105, 1697-1707. [CrossRef] [PubMed]

79. Chae, S.S.; Kamoun, W.S.; Farrar, C.T.; Kirkpatrick, N.D.; Niemeyer, E.; de Graaf, A.M.; Sorensen, A.G.; Munn, L.L.; Jain, R.K.; Fukumura, D. Angiopoietin-2 interferes with anti-VEGFR2-induced vessel normalization and survival benefit in mice bearing gliomas. Clin. Cancer Res. Off. J. Am. Assoc. Cancer Res. 2010, 16, 3618-3627. [CrossRef]

80. Mukherjee, B.; McEllin, B.; Camacho, C.V.; Tomimatsu, N.; Sirasanagandala, S.; Nannepaga, S.; Hatanpaa, K.J.; Mickey, B.; Madden, C.; Maher, E.; et al. EGFRvIII and DNA double-strand break repair: A molecular mechanism for radioresistance in glioblastoma. Cancer Res. 2009, 69, 4252-4259. [CrossRef]

81. Momiyama, M.; Zhao, M.; Kimura, H.; Tran, B.; Chishima, T.; Bouvet, M.; Endo, I.; Hoffman, R.M. Inhibition and eradication of human glioma with tumor-targeting Salmonella typhimurium in an orthotopic nude-mouse model. Cell Cycle 2012, 11, 628-632. [CrossRef]

82. Menon, L.G.; Pratt, J.; Yang, H.W.; Black, P.M.; Sorensen, G.A.; Carroll, R.S. Imaging of human mesenchymal stromal cells: Homing to human brain tumors. J. Neurooncol. 2012, 107, 257-267. [CrossRef]

83. Ahmed, A.U.; Thaci, B.; Alexiades, N.G.; Han, Y.; Qian, S.; Liu, F.; Balyasnikova, I.V.; Ulasov, I.Y.; Aboody, K.S.; Lesniak, M.S. Neural stem cell-based cell carriers enhance therapeutic efficacy of an oncolytic adenovirus in an orthotopic mouse model of human glioblastoma. Mol. Ther. J. Am. Soc. Gene Ther. 2011, 19, 1714-1726. [CrossRef]

84. Fu, Y.; Ong, L.C.; Ranganath, S.H.; Zheng, L.; Kee, I.; Zhan, W.; Yu, S.; Chow, P.K.; Wang, C.H. A Dual Tracer 18F-FCH/18F-FDG PET Imaging of an Orthotopic Brain Tumor Xenograft Model. PLoS ONE 2016, 11, e0148123. [CrossRef] [PubMed]

85. Kirschner, S.; Felix, M.C.; Hartmann, L.; Bierbaum, M.; Maros, M.E.; Kerl, H.U.; Wenz, F.; Glatting, G.; Kramer, M.; Giordano, F.A.; et al. In vivo micro-CT imaging of untreated and irradiated orthotopic glioblastoma xenografts in mice: Capabilities, limitations and a comparison with bioluminescence imaging. J. Neurooncol. 2015, 122, 245-254. [CrossRef]

86. Yin, J.; Kim, J.K.; Moon, J.H.; Beck, S.; Piao, D.; Jin, X.; Kim, S.H.; Lim, Y.C.; Nam, D.H.; You, S.; et al. hMSC-mediated concurrent delivery of endostatin and carboxylesterase to mouse xenografts suppresses glioma initiation and recurrence. Mol. Ther. J. Am. Soc. Gene Ther. 2011, 19, 1161-1169. [CrossRef] [PubMed]

87. von Baumgarten, L.; Brucker, D.; Tirniceru, A.; Kienast, Y.; Grau, S.; Burgold, S.; Herms, J.; Winkler, F. Bevacizumab has differential and dose-dependent effects on glioma blood vessels and tumor cells. Clin. Cancer Res. Off. J. Am. Assoc. Cancer Res. 2011, 17, 6192-6205. [CrossRef]

88. Hayashi, K.; Yamauchi, K.; Yamamoto, N.; Tsuchiya, H.; Tomita, K.; Bouvet, M.; Wessels, J.; Hoffman, R.M. A color-coded orthotopic nude-mouse treatment model of brain-metastatic paralyzing spinal cord cancer that induces angiogenesis and neurogenesis. Cell Prolif. 2009, 42, 75-82. [CrossRef]

89. Khan, N.; Mupparaju, S.; Hou, H.; Williams, B.B.; Swartz, H. Repeated assessment of orthotopic glioma pO(2) by multi-site EPR oximetry: A technique with the potential to guide therapeutic optimization by repeated measurements of oxygen. J. Neurosci. Methods 2012, 204, 111-117. [CrossRef]

90. Kil, W.J.; Cerna, D.; Burgan, W.E.; Beam, K.; Carter, D.; Steeg, P.S.; Tofilon, P.J.; Camphausen, K. In vitro and in vivo radiosensitization induced by the DNA methylating agent temozolomide. Clin. Cancer Res. Off. J. Am. Assoc. Cancer Res. 2008, 14, 931-938. [CrossRef] 
91. Gwak, H.S.; Shingu, T.; Chumbalkar, V.; Hwang, Y.H.; DeJournett, R.; Latha, K.; Koul, D.; Alfred Yung, W.K.; Powis, G.; Farrell, N.P.; et al. Combined action of the dinuclear platinum compound BBR3610 with the PI3-K inhibitor PX-866 in glioblastoma. Int. J. Cancer 2011, 128, 787-796. [CrossRef]

92. Ahmed, A.U.; Tyler, M.A.; Thaci, B.; Alexiades, N.G.; Han, Y.; Ulasov, I.V.; Lesniak, M.S. A comparative study of neural and mesenchymal stem cell-based carriers for oncolytic adenovirus in a model of malignant glioma. Mol. Pharm. 2011, 8, 1559-1572 [CrossRef]

93. Verhoeff, J.J.; Stalpers, L.J.; Claes, A.; Hovinga, K.E.; Musters, G.D.; Peter Vandertop, W.; Richel, D.J.; Leenders, W.P.; van Furth, W.R. Tumour control by whole brain irradiation of anti-VEGF-treated mice bearing intracerebral glioma. Eur. J. Cancer 2009, 45, 3074-3080. [CrossRef]

94. Verhoeff, J.J.; Stalpers, L.J.; Coumou, A.W.; Koedooder, K.; Lavini, C.; Van Noorden, C.J.; Haveman, J.; Vandertop, W.P.; van Furth, W.R. Experimental iodine-125 seed irradiation of intracerebral brain tumors in nude mice. Radiat. Oncol. 2007, 2, 38. [CrossRef]

95. Han, J.H.; Yoon, J.S.; Chang, D.Y.; Cho, K.G.; Lim, J.; Kim, S.S.; Suh-Kim, H. CXCR4-STAT3 Axis Plays a Role in Tumor Cell Infiltration in an Orthotopic Mouse Glioblastoma Model. Mol. Cells 2020, 43, 539-550. [CrossRef]

96. Schötterl, S.; Miemietz, J.T.; Ilina, E.I.; Wirsik, N.M.; Ehrlich, I.; Gall, A.; Huber, S.M.; Lentzen, H.; Mittelbronn, M.; Naumann, U. Mistletoe-Based Drugs Work in Synergy with Radio-Chemotherapy in the Treatment of Glioma In Vitro and In Vivo in Glioblastoma Bearing Mice. Evid. Based Complementary Altern. Med. Ecam 2019, 2019, 1376140. [CrossRef]

97. Verhoye, M.; van der Sanden, B.P.; Rijken, P.F.; Peters, H.P.; Van der Kogel, A.J.; Pée, G.; Vanhoutte, G.; Heerschap, A.; Van der Linden, A. Assessment of the neovascular permeability in glioma xenografts by dynamic T(1) MRI with Gadomer-17. Magn. Reson. Med. 2002, 47, 305-313. [CrossRef]

98. Wang, S.; Khan, A.; Lang, F.F.; Schaefer, T.S. Conditional gene expression in human intracranial xenograft tumors. BioTechniques 2001, 31, 196-202. [CrossRef] [PubMed]

99. Lemke, D.; Pfenning, P.N.; Sahm, F.; Klein, A.C.; Kempf, T.; Warnken, U.; Schnölzer, M.; Tudoran, R.; Weller, M.; Platten, M.; et al. Costimulatory protein $4 \mathrm{IgB7H} 3$ drives the malignant phenotype of glioblastoma by mediating immune escape and invasiveness. Clin. Cancer Res. Off. J. Am. Assoc. Cancer Res. 2012, 18, 105-117. [CrossRef]

100. Camphausen, K.; Purow, B.; Sproull, M.; Scott, T.; Ozawa, T.; Deen, D.F.; Tofilon, P.J. Orthotopic growth of human glioma cells quantitatively and qualitatively influences radiation-induced changes in gene expression. Cancer Res. 2005, 65, 10389-10393. [CrossRef] [PubMed]

101. Xu, Z.F.; Sun, X.K.; Lan, Y.; Han, C.; Zhang, Y.D.; Chen, G. Linarin sensitizes tumor necrosis factor-related apoptosis (TRAIL)induced ligand-triggered apoptosis in human glioma cells and in xenograft nude mice. Biomed. Pharmacother. Biomed. Pharmacother. 2017, 95, 1607-1618. [CrossRef]

102. Park, C.R.; Kim, H.Y.; Song, M.G.; Lee, Y.S.; Youn, H.; Chung, J.K.; Cheon, G.J.; Kang, K.W. Efficacy and Safety of Human Serum Albumin-Cisplatin Complex in U87MG Xenograft Mouse Models. Int. J. Mol. Sci. 2020, 21, 7932. [CrossRef]

103. Palma, C.; Bigioni, M.; Irrissuto, C.; Nardelli, F.; Maggi, C.A.; Manzini, S. Anti-tumour activity of tachykinin NK1 receptor antagonists on human glioma U373 MG xenograft. Br. J. Cancer 2000, 82, 480-487. [CrossRef]

104. Bagci-Onder, T.; Wakimoto, H.; Anderegg, M.; Cameron, C.; Shah, K. A dual PI3K/mTOR inhibitor, PI-103, cooperates with stem cell-delivered TRAIL in experimental glioma models. Cancer Res. 2011, 71, 154-163. [CrossRef]

105. Yuan, A.L.; Ricks, C.B.; Bohm, A.K.; Lun, X.; Maxwell, L.; Safdar, S.; Bukhari, S.; Gerber, A.; Sayeed, W.; Bering, E.A.; et al ABT-888 restores sensitivity in temozolomide resistant glioma cells and xenografts. PLoS ONE 2018, 13, e0202860. [CrossRef]

106. Wakimoto, H.; Mohapatra, G.; Kanai, R.; Curry, W.T., Jr.; Yip, S.; Nitta, M.; Patel, A.P.; Barnard, Z.R.; Stemmer-Rachamimov, A.O.; Louis, D.N.; et al. Maintenance of primary tumor phenotype and genotype in glioblastoma stem cells. Neuro Oncol. 2012, 14, 132-144. [CrossRef]

107. Tanaka, S.; Luk, S.; Kiyokawa, J.; Onozato, M.L.; Iafrate, A.J.; Shah, K.; Martuza, R.L.; Rabkin, S.D.; Batchelor, T.T.; Cahill, D.P.; et al. Genetically distinct glioma stem-like cell xenografts established from paired glioblastoma samples harvested before and after molecularly targeted therapy. Sci. Rep. 2019, 9, 139. [CrossRef]

108. Klink, B.; Miletic, H.; Stieber, D.; Huszthy, P.C.; Valenzuela, J.A.C.; Balss, J.; Wang, J.; Schubert, M.; Sakariassen, P.Ø.; Sundstrøm, T.; et al. A Novel, Diffusely Infiltrative Xenograft Model of Human Anaplastic Oligodendroglioma with Mutations in FUBP1, CIC, and IDH1. PLoS ONE 2013, 8, e59773. [CrossRef]

109. Zeng, W.; Tang, Z.; Li, Y.; Yin, G.; Liu, Z.; Gao, J.; Chen, Y.; Chen, F. Patient-derived xenografts of different grade gliomas retain the heterogeneous histological and genetic features of human gliomas. Cancer Cell Int. 2020, 20, 1. [CrossRef]

110. Ding, H.; Roncari, L.; Shannon, P.; Wu, X.; Lau, N.; Karaskova, J.; Gutmann, D.H.; Squire, J.A.; Nagy, A.; Guha, A. Astrocytespecific expression of activated p21-ras results in malignant astrocytoma formation in a transgenic mouse model of human gliomas. Cancer Res. 2001, 61, 3826-3836. [PubMed]

111. Xue, W.; Ton, H.; Zhang, J.; Xie, T.; Chen, X.; Zhou, B.; Guo, Y.; Fang, J.; Wang, S.; Zhang, W. Patient-derived orthotopic xenograft glioma models fail to replicate the magnetic resonance imaging features of the original patient tumor. Oncol. Rep. 2020, 43, 1619-1629. [CrossRef]

112. Joo, K.M.; Kim, J.; Jin, J.; Kim, M.; Seol, H.J.; Muradov, J.; Yang, H.; Choi, Y.L.; Park, W.Y.; Kong, D.S.; et al. Patient-specific orthotopic glioblastoma xenograft models recapitulate the histopathology and biology of human glioblastomas in situ. Cell Rep. 2013, 3, 260-273. [CrossRef] 
113. Sasaki, A.; Ishiuchi, S.; Kanda, T.; Hasegawa, M.; Nakazato, Y. Analysis of interleukin-6 gene expression in primary human gliomas, glioblastoma xenografts, and glioblastoma cell lines. Brain Tumor Pathol. 2001, 18, 13-21. [CrossRef] [PubMed]

114. Kerstetter-Fogle, A.E.; Harris, P.L.R.; Brady-Kalnay, S.M.; Sloan, A.E. Generation of Glioblastoma Patient-Derived Intracranial Xenografts for Preclinical Studies. Int. J. Mol. Sci. 2020, 21, 5113. [CrossRef]

115. Yamashita, A.S.; da Costa Rosa, M.; Borodovsky, A.; Festuccia, W.T.; Chan, T.; Riggins, G.J. Demethylation and epigenetic modification with 5-azacytidine reduces IDH1 mutant glioma growth in combination with temozolomide. Neuro Oncol. 2019, 21, 189-200. [CrossRef]

116. Sarkaria, J.N.; Carlson, B.L.; Schroeder, M.A.; Grogan, P.; Brown, P.D.; Giannini, C.; Ballman, K.V.; Kitange, G.J.; Guha, A.; Pandita, A.; et al. Use of an orthotopic xenograft model for assessing the effect of epidermal growth factor receptor amplification on glioblastoma radiation response. Clin. Cancer Res. Off. J. Am. Assoc. Cancer Res. 2006, 12, 2264-2271. [CrossRef]

117. Kitange, G.J.; Carlson, B.L.; Mladek, A.C.; Decker, P.A.; Schroeder, M.A.; Wu, W.; Grogan, P.T.; Giannini, C.; Ballman, K.V.; Buckner, J.C.; et al. Evaluation of MGMT promoter methylation status and correlation with temozolomide response in orthotopic glioblastoma xenograft model. J. Neurooncol. 2009, 92, 23-31. [CrossRef]

118. Scigliano, S.; Pinel, S.; Poussier, S.; Fouyssac, F.; Plenat, F.; Karcher, G.; Chastagner, P. Measurement of hypoxia using invasive oxygen-sensitive electrode, pimonidazole binding and 18F-FDG uptake in anaemic or erythropoietin-treated mice bearing human glioma xenografts. Int. J. Oncol. 2008, 32, 69-77. [CrossRef]

119. Wakimoto, H.; Tanaka, S.; Curry, W.T.; Loebel, F.; Zhao, D.; Tateishi, K.; Chen, J.; Klofas, L.K.; Lelic, N.; Kim, J.C.; et al. Targetable signaling pathway mutations are associated with malignant phenotype in IDH-mutant gliomas. Clin. Cancer Res. Off. J. Am. Assoc. Cancer Res. 2014, 20, 2898-2909. [CrossRef]

120. Tiwari, V.; Mashimo, T.; An, Z.; Vemireddy, V.; Piccirillo, S.; Askari, P.; Hulsey, K.M.; Zhang, S.; de Graaf, R.A.; Patel, T.R.; et al. In vivo MRS measurement of 2-hydroxyglutarate in patient-derived IDH-mutant xenograft mouse models versus glioma patients. Magn. Reson. Med. 2020, 84, 1152-1160. [CrossRef]

121. Linninger, A.; Hartung, G.A.; Liu, B.P.; Mirkov, S.; Tangen, K.; Lukas, R.V.; Unruh, D.; James, C.D.; Sarkaria, J.N.; Horbinski, C. Modeling the diffusion of D-2-hydroxyglutarate from IDH1 mutant gliomas in the central nervous system. Neuro Oncol. 2018, 20, 1197-1206. [CrossRef]

122. Day, C.P.; Merlino, G.; Van Dyke, T. Preclinical mouse cancer models: A maze of opportunities and challenges. Cell 2015, 163, 39-53. [CrossRef] [PubMed]

123. Huszthy, P.C.; Daphu, I.; Niclou, S.P.; Stieber, D.; Nigro, J.M.; Sakariassen, P.; Miletic, H.; Thorsen, F.; Bjerkvig, R. In vivo models of primary brain tumors: Pitfalls and perspectives. Neuro Oncol. 2012, 14, 979-993. [CrossRef] [PubMed]

124. Richmond, A.; Su, Y. Mouse xenograft models vs GEM models for human cancer therapeutics. Dis. Model. Mech. 2008, 1, 78-82. [CrossRef] [PubMed]

125. Bosma, G.C.; Custer, R.P.; Bosma, M.J. A severe combined immunodeficiency mutation in the mouse. Nature 1983, 301, 527-530. [CrossRef]

126. Shultz, L.D.; Lyons, B.L.; Burzenski, L.M.; Gott, B.; Chen, X.; Chaleff, S.; Kotb, M.; Gillies, S.D.; King, M.; Mangada, J.; et al. Human lymphoid and myeloid cell development in NOD/LtSz-scid IL2R gamma null mice engrafted with mobilized human hemopoietic stem cells. J. Immunol. 2005, 174, 6477-6489. [CrossRef]

127. da Hora, C.C.; Schweiger, M.W.; Wurdinger, T.; Tannous, B.A. Patient-Derived Glioma Models: From Patients to Dish to Animals. Cells 2019, 8, 1177. [CrossRef] [PubMed]

128. Miyai, M.; Tomita, H.; Soeda, A.; Yano, H.; Iwama, T.; Hara, A. Current trends in mouse models of glioblastoma. J. Neurooncol. 2017, 135, 423-432. [CrossRef]

129. Choi, Y.; Lee, S.; Kim, K.; Kim, S.-H.; Chung, Y.-J.; Lee, C. Studying cancer immunotherapy using patient-derived xenografts (PDXs) in humanized mice. Exp. Mol. Med. 2018, 50, 99. [CrossRef] [PubMed]

130. Morton, J.J.; Bird, G.; Refaeli, Y.; Jimeno, A. Humanized Mouse Xenograft Models: Narrowing the Tumor-Microenvironment Gap. Cancer Res. 2016, 76, 6153-6158. [CrossRef]

131. Semenkow, S.; Li, S.; Kahlert, U.D.; Raabe, E.H.; Xu, J.; Arnold, A.; Janowski, M.; Chol Oh, B.; Brandacher, G.; Bulte, J.W.M.; et al. An immunocompetent mouse model of human glioblastoma. Oncotarget 2017, 8, 61072. [CrossRef]

132. House, C.D.; Hernandez, L.; Annunziata, C.M. Recent technological advances in using mouse models to study ovarian cancer. Front. Oncol. 2014, 4, 26. [CrossRef] [PubMed]

133. Da Silva, B.; Mathew, R.K.; Polson, E.S.; Williams, J.; Wurdak, H. Spontaneous Glioblastoma Spheroid Infiltration of Early-Stage Cerebral Organoids Models Brain Tumor Invasion. Slas Discov. Adv. Life Sci. R D 2018, 23, 862-868. [CrossRef]

134. Song, H.K.; Hwang, D.Y. Use of C57BL/6N mice on the variety of immunological researches. Lab. Anim. Res. 2017, 33, 119-123. [CrossRef]

135. Trunova, G.V.; Makarova, O.V.; Diatroptov, M.E.; Bogdanova, I.M.; Mikchailova, L.P.; Abdulaeva, S.O. Morphofunctional characteristic of the immune system in BALB/c and C57BL/6 mice. Bull. Exp. Biol. Med. 2011, 151, 99-102. [CrossRef]

136. Taketo, M.; Schroeder, A.C.; Mobraaten, L.E.; Gunning, K.B.; Hanten, G.; Fox, R.R.; Roderick, T.H.; Stewart, C.L.; Lilly, F.; Hansen, C.T.; et al. FVB/N: An inbred mouse strain preferable for transgenic analyses. Proc. Natl. Acad. Sci. USA 1991, 88, 2065-2069. [CrossRef] [PubMed]

137. Kim, E.M.; Bae, Y.M.; Choi, M.H.; Hong, S.T. Cyst formation, increased anti-inflammatory cytokines and expression of chemokines support for Clonorchis sinensis infection in FVB mice. Parasitol. Int. 2012, 61, 124-129. [CrossRef] 
138. Hede, S.M.; Hansson, I.; Afink, G.B.; Eriksson, A.; Nazarenko, I.; Andrae, J.; Genove, G.; Westermark, B.; Nistér, M. GFAP promoter driven transgenic expression of PDGFB in the mouse brain leads to glioblastoma in a Trp53 null background. Glia 2009, 57, 1143-1153. [CrossRef]

139. Vitucci, M.; Irvin, D.M.; McNeill, R.S.; Schmid, R.S.; Simon, J.M.; Dhruv, H.D.; Siegel, M.B.; Werneke, A.M.; Bash, R.E.; Kim, S.; et al. Genomic profiles of low-grade murine gliomas evolve during progression to glioblastoma. Neuro Oncol. 2017, 19, 1237-1247. [CrossRef]

140. Zhu, Y.; Guignard, F.; Zhao, D.; Liu, L.; Burns, D.K.; Mason, R.P.; Messing, A.; Parada, L.F. Early inactivation of p53 tumor suppressor gene cooperating with NF1 loss induces malignant astrocytoma. Cancer Cell 2005, 8, 119-130. [CrossRef] [PubMed]

141. Xiao, A.; Wu, H.; Pandolfi, P.P.; Louis, D.N.; Van Dyke, T. Astrocyte inactivation of the pRb pathway predisposes mice to malignant astrocytoma development that is accelerated by PTEN mutation. Cancer Cell 2002, 1, 157-168. [CrossRef]

142. Xiao, A.; Yin, C.; Yang, C.; Di Cristofano, A.; Pandolfi, P.P.; Van Dyke, T. Somatic induction of Pten loss in a preclinical astrocytoma model reveals major roles in disease progression and avenues for target discovery and validation. Cancer Res. 2005, 65, 5172-5180. [CrossRef]

143. Sasaki, M.; Knobbe, C.B.; Itsumi, M.; Elia, A.J.; Harris, I.S.; Chio, I.I.; Cairns, R.A.; McCracken, S.; Wakeham, A.; Haight, J.; et al. D-2-hydroxyglutarate produced by mutant IDH1 perturbs collagen maturation and basement membrane function. Genes Dev. 2012, 26, 2038-2049. [CrossRef]

144. Lindberg, N.; Kastemar, M.; Olofsson, T.; Smits, A.; Uhrbom, L. Oligodendrocyte progenitor cells can act as cell of origin for experimental glioma. Oncogene 2009, 28, 2266-2275. [CrossRef]

145. Uhrbom, L.; Kastemar, M.; Johansson, F.K.; Westermark, B.; Holland, E.C. Cell type-specific tumor suppression by Ink4a and Arf in Kras-induced mouse gliomagenesis. Cancer Res. 2005, 65, 2065-2069. [CrossRef] [PubMed]

146. Uhrbom, L.; Dai, C.; Celestino, J.C.; Rosenblum, M.K.; Fuller, G.N.; Holland, E.C. Ink4a-Arf loss cooperates with KRas activation in astrocytes and neural progenitors to generate glioblastomas of various morphologies depending on activated Akt. Cancer Res. 2002, 62, 5551-5558. [PubMed]

147. Hambardzumyan, D.; Amankulor, N.M.; Helmy, K.Y.; Becher, O.J.; Holland, E.C. Modeling Adult Gliomas Using RCAS/t-va Technology. Transl. Oncol. 2009, 2, 89-95. [CrossRef] [PubMed]

148. Jiang, Y.; Boije, M.; Westermark, B.; Uhrbom, L. PDGF-B Can sustain self-renewal and tumorigenicity of experimental gliomaderived cancer-initiating cells by preventing oligodendrocyte differentiation. Neoplasia 2011, 13, 492-503. [CrossRef]

149. Uhrbom, L.; Hesselager, G.; Ostman, A.; Nistér, M.; Westermark, B. Dependence of autocrine growth factor stimulation in platelet-derived growth factor-B-induced mouse brain tumor cells. Int. J. Cancer 2000, 85, 398-406. [CrossRef]

150. Amankulor, N.M.; Kim, Y.; Arora, S.; Kargl, J.; Szulzewsky, F.; Hanke, M.; Margineantu, D.H.; Rao, A.; Bolouri, H.; Delrow, J.; et al. Mutant IDH1 regulates the tumor-associated immune system in gliomas. Genes Dev. 2017, 31, 774-786. [CrossRef]

151. Kwon, C.H.; Zhao, D.; Chen, J.; Alcantara, S.; Li, Y.; Burns, D.K.; Mason, R.P.; Lee, E.Y.; Wu, H.; Parada, L.F. Pten haploinsufficiency accelerates formation of high-grade astrocytomas. Cancer Res. 2008, 68, 3286-3294. [CrossRef]

152. de Vries, N.A.; Bruggeman, S.W.; Hulsman, D.; de Vries, H.I.; Zevenhoven, J.; Buckle, T.; Hamans, B.C.; Leenders, W.P.; Beijnen, J.H.; van Lohuizen, M.; et al. Rapid and robust transgenic high-grade glioma mouse models for therapy intervention studies. Clin. Cancer Res. Off. J. Am. Assoc. Cancer Res. 2010, 16, 3431-3441. [CrossRef]

153. Zhu, H.; Acquaviva, J.; Ramachandran, P.; Boskovitz, A.; Woolfenden, S.; Pfannl, R.; Bronson, R.T.; Chen, J.W.; Weissleder, R.; Housman, D.E.; et al. Oncogenic EGFR signaling cooperates with loss of tumor suppressor gene functions in gliomagenesis. Proc. Natl. Acad. Sci. USA 2009, 106, 2712-2716. [CrossRef] [PubMed]

154. Uhrbom, L.; Hesselager, G.; Nistér, M.; Westermark, B. Induction of brain tumors in mice using a recombinant platelet-derived growth factor B-chain retrovirus. Cancer Res. 1998, 58, 5275-5279.

155. Nunez, F.J.; Mendez, F.M.; Kadiyala, P.; Alghamri, M.S.; Savelieff, M.G.; Garcia-Fabiani, M.B.; Haase, S.; Koschmann, C.; Calinescu, A.A.; Kamran, N.; et al. IDH1-R132H acts as a tumor suppressor in glioma via epigenetic up-regulation of the DNA damage response. Sci. Transl. Med. 2019, 11. [CrossRef]

156. Wei, Q.; Clarke, L.; Scheidenhelm, D.K.; Qian, B.; Tong, A.; Sabha, N.; Karim, Z.; Bock, N.A.; Reti, R.; Swoboda, R.; et al. High-grade glioma formation results from postnatal pten loss or mutant epidermal growth factor receptor expression in a transgenic mouse glioma model. Cancer Res. 2006, 66, 7429-7437. [CrossRef]

157. Bender, A.M.; Collier, L.S.; Rodriguez, F.J.; Tieu, C.; Larson, J.D.; Halder, C.; Mahlum, E.; Kollmeyer, T.M.; Akagi, K.; Sarkar, G.; et al. Sleeping beauty-mediated somatic mutagenesis implicates CSF1 in the formation of high-grade astrocytomas. Cancer Res. 2010, 70, 3557-3565. [CrossRef]

158. Marumoto, T.; Tashiro, A.; Friedmann-Morvinski, D.; Scadeng, M.; Soda, Y.; Gage, F.H.; Verma, I.M. Development of a novel mouse glioma model using lentiviral vectors. Nat. Med. 2009, 15, 110-116. [CrossRef] [PubMed]

159. Rankin, S.L.; Zhu, G.; Baker, S.J. Review: Insights gained from modelling high-grade glioma in the mouse. Neuropathol. Appl. Neurobiol. 2012, 38, 254-270. [CrossRef]

160. Ahronian, L.G.; Lewis, B.C. Using the RCAS-TVA system to model human cancer in mice. Cold Spring Harb. Protoc. 2014, 2014, 1128-1135. [CrossRef] [PubMed]

161. Holland, E.C.; Varmus, H.E. Basic fibroblast growth factor induces cell migration and proliferation after glia-specific gene transfer in mice. Proc. Natl. Acad. Sci. USA 1998, 95, 1218-1223. [CrossRef] 
162. Holland, E.C.; Hively, W.P.; DePinho, R.A.; Varmus, H.E. A constitutively active epidermal growth factor receptor cooperates with disruption of G1 cell-cycle arrest pathways to induce glioma-like lesions in mice. Genes Dev. 1998, 12, 3675-3685. [CrossRef] [PubMed]

163. Bouabe, H.; Okkenhaug, K. Gene targeting in mice: A review. Methods Mol. Biol. 2013, 1064, 315-336. [CrossRef]

164. Kim, A.H.; Kim, S.P. Surviving travel or travelling to survive: The association of travel distance with survival in muscle invasive bladder cancer. Transl. Androl. Urol. 2018, 7, S83-S85. [CrossRef] [PubMed]

165. Mignone, J.L.; Kukekov, V.; Chiang, A.S.; Steindler, D.; Enikolopov, G. Neural stem and progenitor cells in nestin-GFP transgenic mice. J. Comp. Neurol. 2004, 469, 311-324. [CrossRef] [PubMed]

166. Weissenberger, J.; Steinbach, J.; Malin, G.; Spada, S.; Rülicke, T.; Aguzzi, A. Development and malignant progression of astrocytomas in GFAP-v. Oncogene 1997, 14, 2005-2013. [CrossRef]

167. Reilly, K.M.; Loisel, D.A.; Bronson, R.T.; McLaughlin, M.E.; Jacks, T. Nf1;Trp53 mutant mice develop glioblastoma with evidence of strain-specific effects. Nat. Genet. 2000, 26, 109-113. [CrossRef]

168. Borodovsky, A.; Meeker, A.K.; Kirkness, E.F.; Zhao, Q.; Eberhart, C.G.; Gallia, G.L.; Riggins, G.J. A model of a patient-derived IDH1 mutant anaplastic astrocytoma with alternative lengthening of telomeres. J. Neurooncol. 2015, 121, 479-487. [CrossRef]

169. Yang, H.; Ye, D.; Guan, K.L.; Xiong, Y. IDH1 and IDH2 mutations in tumorigenesis: Mechanistic insights and clinical perspectives. Clin. Cancer Res. Off. J. Am. Assoc. Cancer Res. 2012, 18, 5562-5571. [CrossRef]

170. Philip, B.; Yu, D.X.; Silvis, M.R.; Shin, C.H.; Robinson, J.P.; Robinson, G.L.; Welker, A.E.; Angel, S.N.; Tripp, S.R.; Sonnen, J.A.; et al. Mutant IDH1 Promotes Glioma Formation In Vivo. Cell Rep. 2018, 23, 1553-1564. [CrossRef]

171. Tateishi, K.; Wakimoto, H.; Iafrate, A.J.; Tanaka, S.; Loebel, F.; Lelic, N.; Wiederschain, D.; Bedel, O.; Deng, G.; Zhang, B.; et al. Extreme Vulnerability of IDH1 Mutant Cancers to NAD+ Depletion. Cancer Cell 2015, 28, 773-784. [CrossRef]

172. Rohle, D.; Popovici-Muller, J.; Palaskas, N.; Turcan, S.; Grommes, C.; Campos, C.; Tsoi, J.; Clark, O.; Oldrini, B.; Komisopoulou, E.; et al. An Inhibitor of Mutant IDH1 Delays Growth and Promotes Differentiation of Glioma Cells. Science 2013, 340, 626-630. [CrossRef]

173. Schumacher, T.; Bunse, L.; Pusch, S.; Sahm, F.; Wiestler, B.; Quandt, J.; Menn, O.; Osswald, M.; Oezen, I.; Ott, M.; et al. A vaccine targeting mutant IDH1 induces antitumour immunity. Nature 2014, 512, 324-327. [CrossRef] [PubMed]

174. Huang, J.; Yu, J.; Tu, L.; Huang, N.; Li, H.; Luo, Y. Isocitrate Dehydrogenase Mutations in Glioma: From Basic Discovery to Therapeutics Development. Front. Oncol. 2019, 9, 506. [CrossRef] [PubMed]

175. Graham, M.S.; Mellinghoff, I.K. Histone-Mutant Glioma: Molecular Mechanisms, Preclinical Models, and Implications for Therapy. Int. J. Mol. Sci. 2020, 21, 7193. [CrossRef] [PubMed]

176. Lowe, B.R.; Maxham, L.A.; Hamey, J.J.; Wilkins, M.R.; Partridge, J.F. Histone H3 Mutations: An Updated View of Their Role in Chromatin Deregulation and Cancer. Cancers 2019, 11, 660. [CrossRef] [PubMed]

177. Mosaab, A.; El-Ayadi, M.; Khorshed, E.N.; Amer, N.; Refaat, A.; El-Beltagy, M.; Hassan, Z.; Soror, S.H.; Zaghloul, M.S.; El-Naggar, S. Histone H3K27M Mutation Overrides Histological Grading in Pediatric Gliomas. Sci. Rep. 2020, 10, 8368. [CrossRef] 